\title{
DISCLAIMER DR-1797-3
}

This report was prepared as an account of work sponsored by an agency of the United States Government. Neither the United States Government nor any agency thereof, nor any of their employees, makes any warranty, express or implied, or assumes any legal liability or responsibility for the accuracy, completeness, or usefulness of any information, apparatus, product, or process disclosed, or represents that its use would not infringe privately owned rights. Reference herein to any specific commercial product, process, or service by trade name, trademark, manufacturer, or otherwise does not necessarily constitute or imply its endorsement, recommendation, or favoring by the United States Government or any agency thereof. The views and opinions of authors expressed herein do not necessarily state or reflect those of the United States Government or any agency thereof.
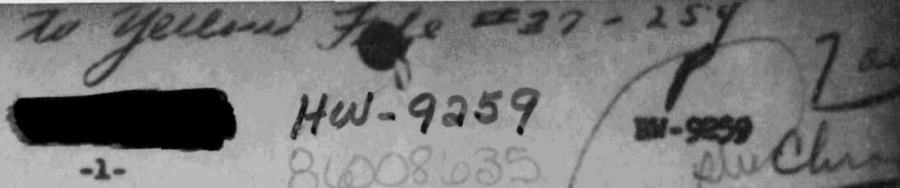

\section{Cops 1 - I Iavdor - 60 Las 1

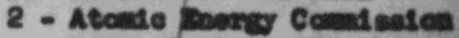 Att: Carieton $\mathbf{2}$. Bhues

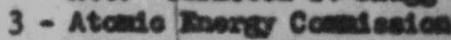 Ate: D. Bhelde Warron a. Masila}

HW --9259

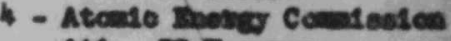
Att: $\mathrm{BC}$ Engoman

5. Atorie Buerg Comisaton Atts As cornas

6 - its churab

7 - or Crose - vir thecruedy

8 - As Grvetrenr - as Wort

9 - En Parteor - oc Denerteselest

10 - $N$ Eoaly - 26 ghortars w singloviah

11 - 5 wilsos

12 - CW Pattareca - In, Milobelean

13 - $300 \mathrm{F110}$

14 - $700 \mathrm{FH}$

15 - Drtas 7410 RECOR PECOR

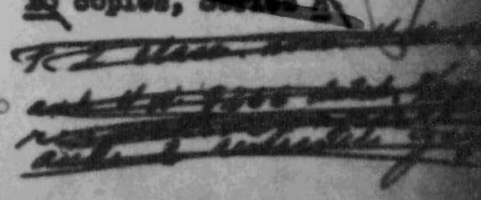

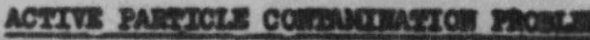

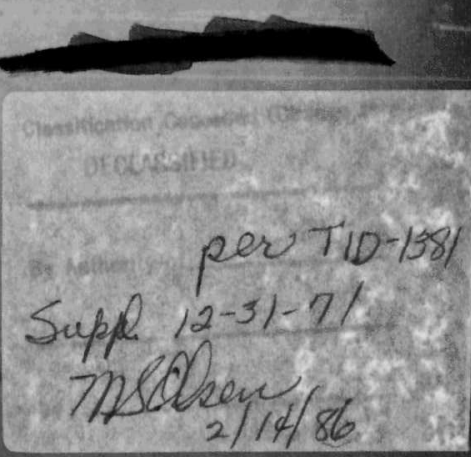

Ars I. M. Partoex

Dates Hured ae, 2948

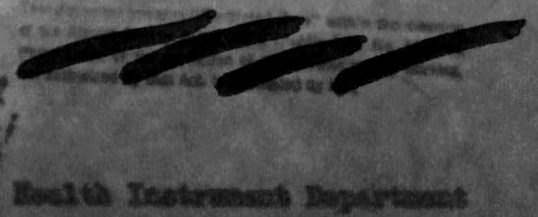




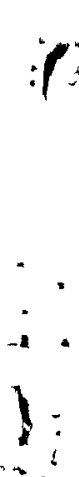

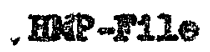

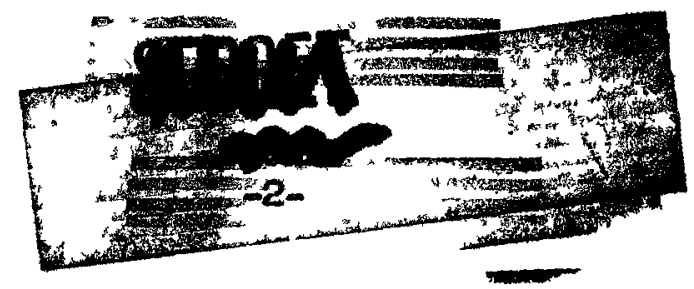

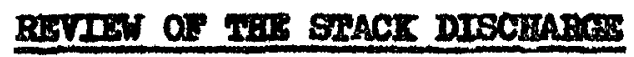

\section{ACLIVE PAFMICIS COLHAMITATIOI PROBRIA}

Introdnotion

A Irport hy M.I. Mickelean", two earlier reportg by the wrotexw, a report by R.8. BeII", and mmerous incldental reforenoesiff have defined the problen end Indicated scing of the actions talen to correct hazardous conditions. This raport will attempt to bring this data up to dsto, and to include more of the studios and actions of all departmonts than eppeared in the earlior H.I. roport. For this reason, and also because the emphasis an the varlous proposed tosts has changed considerably, tho paragrapining ateen of the earlior H.I. reports vill be abendoned. As the contaninating agent has been rarlougly roferred to as epecks, spots and ective perticles, it 1s proposod that a uniform titie of "Stack Disahargo Active Particlo Contamination" be applied to the probleze in future. The Interpretation has to be broad enough to cover droplets, niet or opray as vell as discrote solld particlos.

1. Blological Invostigations

The blologicel atudy has been Iimited to a litoraturo reviow and to a sicetaing exploriatory experimontal program. The literature roviou was esaentially vorthiees. Beported reaults were concerned primarily with the blologlcel

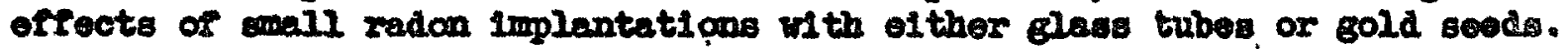

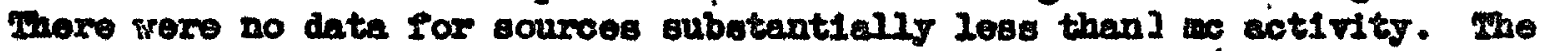
search was modo at a timo whon fairly aicoeble particlos (approximately $0.1 \mathrm{~mm}$ ) wore considerod. It Is now clear that the actual problems range all the way down to ultre-fine particles - effectively eerosols. Tho rathor extengive 11 tereture on redicective aerosol contamination has not yot boon roviewod. It is owr uderstanding that wuch rosults havo not been particularly concernod with, or ouccesstul in dotecting locel denags In the Iunge from the doposttion of fine particles. Dr. F. E. Church has Indicated that the Chemicel Harfere Service has made extensivo investigaticns on the elzes of particles that can penotrate the human defonse and onter the lung. Th1 source is to be tappod, and may loed to a concentration of the blological investigation on a rather restricted range of particlo alze (porhepe 1 to 5 microns).

Project rork on eerosole Indicates that $I$, Ce and Pr are in the emall croup of flaston products whioh is owsentially rotainod in the lung. A these three are responalble for most of the activity of the perticles in question, it is constdered cortain that the limsting haxard vill bo the

"Preliminary Report on Friloting Act1ve Particle Fasard - 200 Arsea". M.I. Mckelson - 10/22/47 (Doc. HW-7865)

** "Action taken an the Spot Contemination in the Separations Plant Arees" I.M. Parker 10/30/47 (Doc. HW-7920) Progress Boport on "Action takon on the Spot Contemination in the Separatione Plant Areas" I.H. Paricer 1/20/48 (Doc. BUT-8624).

"Active Particie Invertigation - 200 Areas - Betabliahmont of Physical Control" R.S. Be11 11/26/47 (Doc. IN-8108)

\# The flret documonted reference is apperonth Arwas and Asscolated Iaboratorlog How Fond W.K. Maccready (Doc. EN-7695 


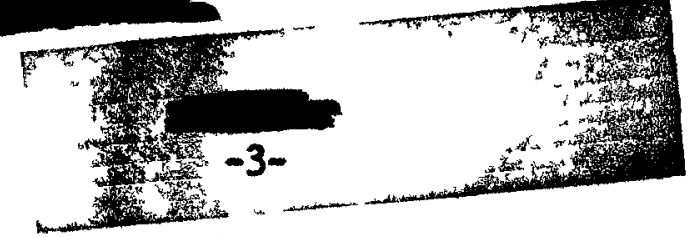

100al Irradiation of Iuns tibeno. In any cave, the total activity involvod 18 00 low that aseinilation 1nto the blood otroem and gubesquent doposition In an organ would oertalnly be imocuons, unlese one has to mppose that aerosole have been inbaled sinoe the staxt of operations. One speculates that even this vould be entirely eafe, and thet radicactivity vould bo demonstrable in the urino or foces long bofore a haxardous accumulation had been achlered. No onch activity 18 found.

Blological expeximents have been as follows:

a. Solubility of the aotive partieles in human gagtrie guloe

Solubility was aogilefble in the juice of each of two oubjocts toated (orior of 1 s diesolved).

b. Absorption in G.I. tract of guinge pige, rats and rabbite

thore wa 1nstgnificant absorption in all triels. Both (a) and (b) are cowowhat ourprising in view of the known bigh absorbability of Ce. In both experimonte the epecke were broken down by the gaetric julce into much enaller perticles. The intital introduction of rery rino particlea might woll have Iod to moh greater absorption.

c. Tracheal cammiation of rabbite

The active particles vero removed, presumably by clliary action, in the Iour opecinons.

\section{d. Surfece irradiation of rabbit ear}

Pour anfmale were expoesd for timos betrieen one and four months to wpeck of about 0.5 to 1 pe activity. Dublous reection was noted in one instance, iv the fori of recurront reddish brown plemontetion. The reader is entitiled to note that the wori was dons vith roddish brown epecirs of contaninated Iron arddo. A provioudy reparted thickoning of an car also has an equivocel status. Inactive control apecke produced no ixritation reactions.

- Spboutanoour implentation - rabbits

The implaats have been in place in four rabbits for $3 \frac{1}{2}$ months. No surface renction 1s observod. The animals have not got boen bacrifleed for histalogical atudy.

\section{f. Teatioular implanta - rabbits}

Four antmals were implantod with active particles, together with 3 inactive control opecks. Ono animal, eacriflced at two months wowed no erose 10810n, but thore was no oporn ithin a radius of $2 \mathrm{~mm}$. of tho apeck. Also thoro vas an increase in the amount of tiesue accopting an acid stain (oosin).

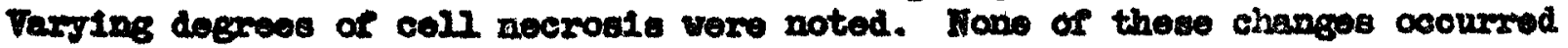
In the coutrol tonticle.

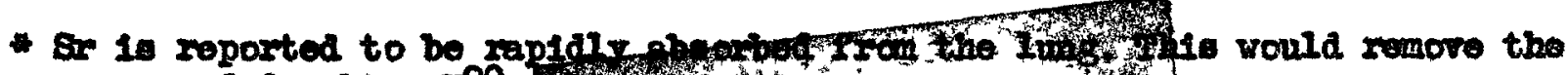
nouree of daughter 790 . 


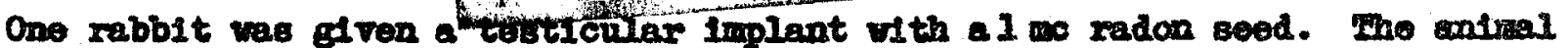
wes exerficed after 2 month; the vections have not jot been studied. The purpose here was to correlate active partielo damsge with the wore or loss Inown demage Irom radom seod implants.

\section{Ispoevire of rabbits noer the I Plant Btack}

Elghtoen anima is so exposed havo dhom no sctirity due to particles an tho fur, except on the foot. Whother milaly aotive particles are in the 2 ung can only bo found by autopay. The cone antmal sacmlleod was clean.

Sumary of thiniting on blologioal eapects.

The avallabio active particles can produce radiation dambe. Thore will bo wo ralble reaction on the aldin.

The critical harard is the inhalation and Iung rotention of particlos.

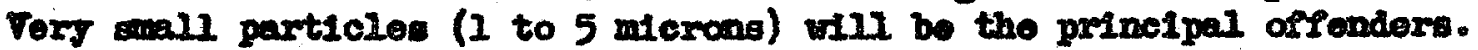
It 111 be imposalble to dofino the safe permierible aotivity of such particles in a short trin experimant.

Cantinued absence of redicactivity in the feces could be used as prominptive erldence of Insignificant deposition following ingesticn of particles. This 18 also a probably adequate doterminant of ebsence of gonervilized lung doposition on the asoumption that a sionificant fraction of the Intilal depontion vould be renoved and would fallow the Ingegtion routio. It io proposed to ask Dr. R. R. Zirtclo and Dr. S. F. Cantril for a wore authoritative interprotation of this work, and for guidance on the trature program.

2. Discovery and Origin of the Particles

\section{Conoral}

The cocurrence of contamination in the form of discrote active particlos on the ground in the Separations Plants wes dotected in lato September 1947, by I. I. enurveyore. It follawed from the flnding of activity at the baese of the I Plant Canjon, Iran recurxent contamination of a path outelds the B Plant Control Laboratory, and fron shoo contemination of a patrolman, wich led to Iinding contanination near a guard tonor. By ma-Dotober the

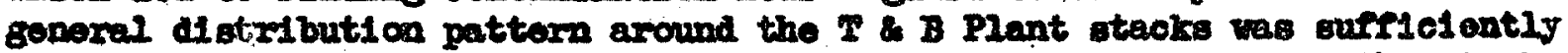
well definod to make it cortain that the particloe evanated from the atacirs. At that time, it was folt that the phenononon might have oristed for aeveral monthe\# of thout dotoctica. A roview of the contemilation deta suggested that the megnitude of the effect had been inoreasing quito rapldy prior to Ito discovery.

The particles vere orlginally eeparated by hand Prom the adjacent and grains. It wal later found that thoy could uowalis bo diotingulahod by ojo, dno to thols roddish brown colloretion. Chemical analysis ahowod an approctinto 50,3 content of $\mathrm{Fe}_{2} \mathrm{O}_{3}$, and about the wame timo it was roulleod that the

\# Contaminated coll dotocted near the 1 Plant Ponco duxprothe vool onding

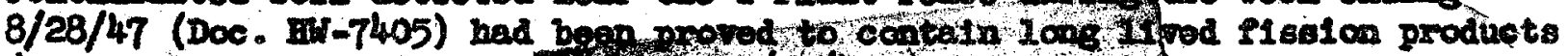

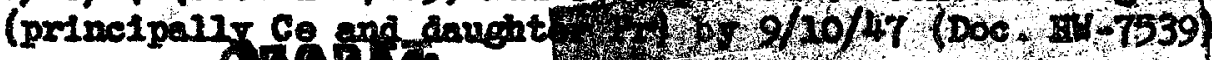




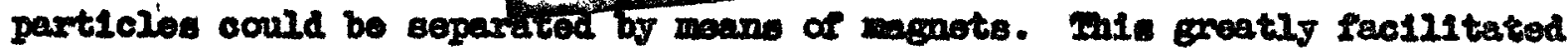
the preparstion of aamplos for chemical and phralcal atudy.

\section{Oxisedn}

Those stud1es proved the prosenoe of long-Il ved flasion products coly, together with trace amounts of alpha-culttere. Prontnent innetive elemente prosent vere B1, Fe and S1. By late Iorember, it had been establiched that the carrier particles wore corrosion products frem black 1rom in the stack Pen ductroxk, wich was apposed to have been atainlose steel throughout. In early noveriber, a progervin we initlated to install filtors in tho ventilation ductwors as olowe to the otweks as possible, to basdlo all process buliding ventilation alr. The radiation hacards involved in ao-

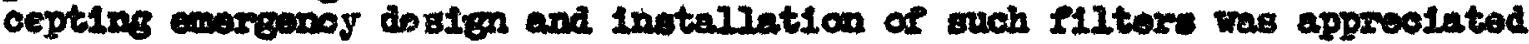
by all canosrned. Conequently, wen the orletin of the main carrier parificles assicnod to the improper ductwork, it was loglcal to euppose that correction of the drotwork wes an adoquate atop for the imadiato future, learing the alreedy proposed full ethdy of the filtretion problea to a Ietor date. Orders nare ohangeder to postpone the installetios of PIItore indefint tols and to proceod with tho fan and duot replacemont. This ohange was in any case u rgent to aroid the riak of corrosion to the polnt of collepse.

The work of the Technical and H. I. Departwonts subeequently made it clear that although the large particlos on which attention was focused in tho oarlier atudies vere oliminsted by the fen changee, morous anallor

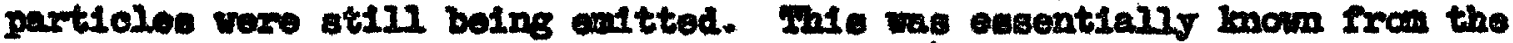
moasurenonts by F. P. Sogmour in Fobruary 1945. The then-asenmod droplet contemination was assumod to bo diepereod and diluted in the same manner as the 10dine, wich was then the exitical contaninant. Caloulations of the possible concentration of Pleston producte at the ground (approximatels

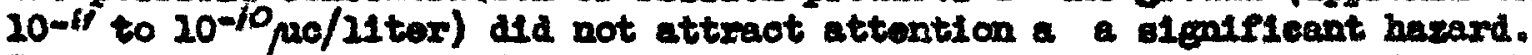
Sporadic moesurements of the deposition on vegotation have been made ulth no more then treces loceted.

Speclfically, the large active particles (>0.1 m.) came fran the corrodod ductwork. At the present tims thero are mmoroun cuncll particles, some of thich are magnotic and thorefore probably excon the wene souroe, together ith ultere fine particles or droplets direotly from the procese voseals. Such droplete mas also intilelly conteminate dust paxticles pulled through the ventilation aratem.

3 Distribution of active pertioles

In10 problem logicalis divided into Pechnieal Department atudles of the

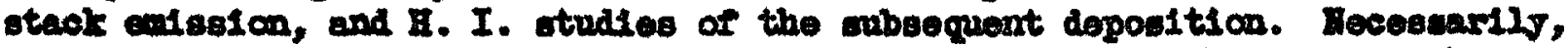
there has been overlap and effective cooperation in the fleld betweon the dopertwonts. Superfielally, there heve been epparent conflicts in the various reports. Ione of thess is real, and nost of them have been due to a progreeaive increase in ald 21 in detection of invisible partieles. Thore has been nelther time nor manporror to revive the earlier date to malo it conolstent in this reopect.

Wroject Doalen Boquost to W.W. Pleasants Ixan W.X. Laegready - $11 / 3 / 47$

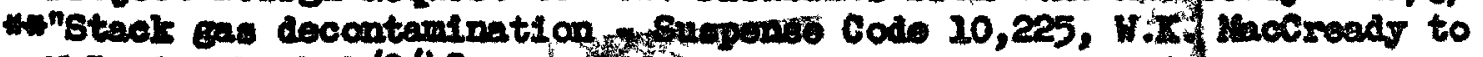
W.P. Overbeck $2 / 8 / 48$. 
a. The Zechnical Departmont proftum an Steck emiegion

Ths Btack Cas Dipposel group tranaforred 1ts Interest fran the Il31 problem ts the particle problem on 11/1/48* (Doo. Di-8074). Four prineipel

oumpling position wth Filters were ostabliehod in the B Plant.

1. Canyon alr prior to entering the fans - through the air balanoe duot. Avaliabie $11 / 17 / 48$.

2. Cumpon alr beyone the fan - through the accese door in duxt. Avallable 11/25/48.

3. Mesalver arf-gas. Ara12ab2e 11/30/48.

4. Stack air at the 50 soot 10rel. Avallablo $11 / 17 / 48$.

Iypteal ample reaults vore:

\begin{tabular}{|c|c|c|c|c|c|c|}
\hline Sarple & $\begin{array}{l}\text { Duration } \\
\text { Eorirg }\end{array}$ & $\begin{array}{l}\text { Row } \\
\text { One }\end{array}$ & 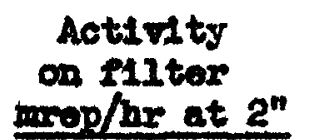 & Remarize & Beferonce & \\
\hline I-1 & 3 & 10 & 1500 & 2 particlos & an-8234 & \\
\hline $\mathbf{n}-\mathbf{2}$ & 18 & 10 & 1500 & $1 \operatorname{partic20}$ & $21 / 16 / 47$ & :..:: \\
\hline $54-1$ & 2 & 10 & 325 & $\begin{array}{l}400-500 \\
\text { particles }\end{array}$ & & $\ldots . . .$. \\
\hline $54-2$ & 2 & 10 & 5 (at4") & 108s than $74-1$ & & $\because \because:$ \\
\hline $24-4$ & $22 \frac{1}{2}$ & 10 & 3300 & $<25$, but not & & $\because \because:$ \\
\hline $54-5$ & 5 & 10 & 1500 & $>100$ particles & & $\ldots . . .:$ \\
\hline re-1* & 4t & 21 & 480 & many partieles & Ex-8235 & :...... \\
\hline $32-2+1]$ & 6 & 11 & 180 & more particles & $11 / 23 / 47$ & :....:: \\
\hline re-3 & 4 & 15 & 350 & most \& hottest & & \\
\hline $54-7 *$ & $4 \frac{1}{2}$ & 20 & 350 & $\begin{array}{l}\text { fino sise hot } \\
\text { pertialos }\end{array}$ & & \\
\hline $84-8 \cdots$ & 6 & 10 & 300 & 21ke $74-7$ & & \\
\hline $20-4$ & $24 \frac{2}{2}$ & 10 & 3000 & $\begin{array}{l}\text { most particlos } \\
\text { jot collocted }\end{array}$ & $\mathrm{Bw}-8422$ & \\
\hline T4-9" & $10 \frac{2}{2}$ & & 0 & 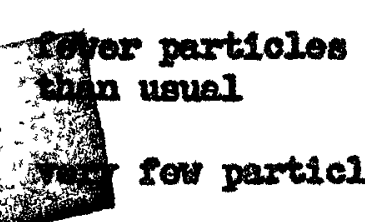 & $21 / 30 / 47$ & 3 \\
\hline
\end{tabular}




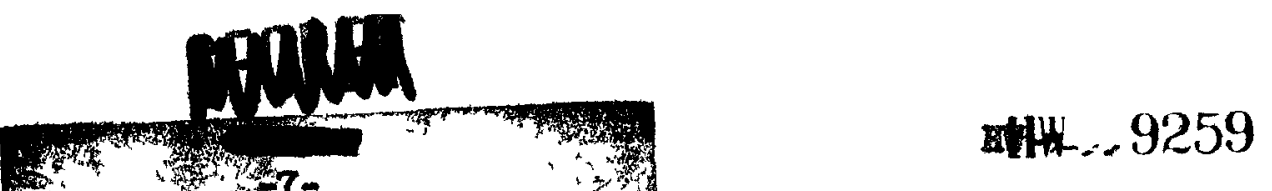

\begin{tabular}{|c|c|c|c|c|}
\hline Eample & $\begin{array}{l}\text { Duration } \\
\text { Eoure }\end{array}$ & an & meo/hr at e" & E.max \\
\hline $32-6 w$ & $27-2 / 3$ & 10 & 480 & $\begin{array}{l}\text { fower then } \\
\text { neruel }\end{array}$ \\
\hline $24-2004$ & $17-1 / 3$ & 10 & 480 & $\begin{array}{l}\text { pract. no } \\
\text { partiolo }\end{array}$ \\
\hline $23-1$ & 2 & 20 & 3000 & $\begin{array}{l}\text { no alseoloing } \\
\text { no pertiolo }\end{array}$ \\
\hline $23-2$ & 2 & 10 & 33,000 & $\begin{array}{l}\text { P12ret out - } \\
\text { no partstolo }\end{array}$ \\
\hline
\end{tabular}

ductuorit and cos fan repleced at this potnt

\begin{tabular}{|c|c|c|c|c|c|}
\hline $32-9$ & 23.7 & 10.5 & 7500 & mang partiolos & W-8704 \\
\hline $74-12 *$ & 23.8 & 20 & 3000 & no pesticle & $2 / 21 / 48$ \\
\hline re-10w & 24 & 20 & 2500 & $\begin{array}{l}\text { covoral oull } \\
\text { particles }\end{array}$ & \\
\hline$-34-12$ & 24 & 10 & 2500 & con large an & \\
\hline $2 x-11 *$ & 25 & 10 & 3000 & $\begin{array}{l}\text { nowe viatbie } \\
\text { I.I. Pound } 47\end{array}$ & EN -8705 \\
\hline $24-13 x$ & 25 & 20 & 2500 & $\begin{array}{l}7 \text { tatbio } \\
\text { B.I. Iound } 57\end{array}$ & $1 / 18 / 48$ \\
\hline M-5 & 23 & 12 & 5000 & $\begin{array}{l}\text { none velble } \\
\text { I.I. found } 1\end{array}$ & $7 x-8953$ \\
\hline $2-6$ & 72 & 12 & 8000 & $\begin{array}{l}\text { none viatble } \\
\text { E.I. Tound } 40\end{array}$ & $1 / 25 / 48$ \\
\hline
\end{tabular}

- and ind incatos simultanocus asaplos.

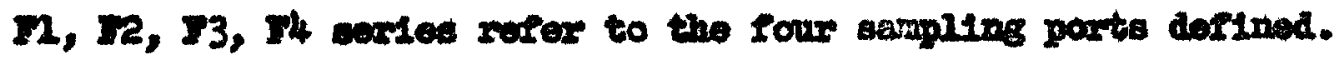

2wo gonerul consluations doduod from thoes data wores

Exion to dnet thange

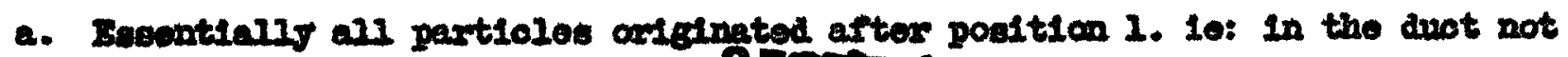
Iroce the procent veswels.

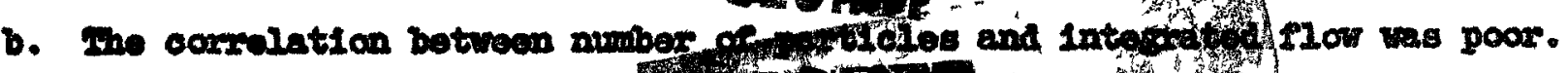
After Doot ahnoge

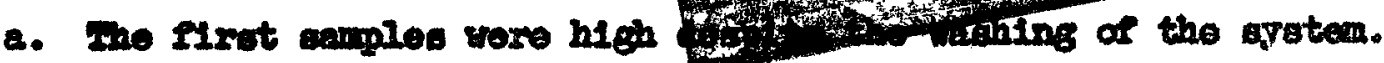




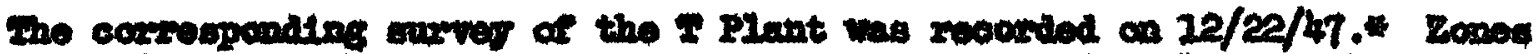

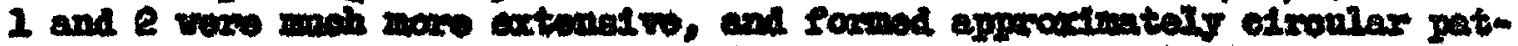

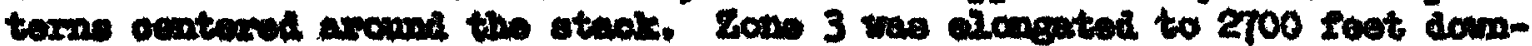
vind, vat hew extented 800 toot upwish.

2000 $1-50,000$ ax. It., $4 \times 10^{6}$ partioles

$20002-640,000$ 0q. It., $2.5 \times 206$ youttales

$20003-4,200,000$ aq. At., if $210^{4}$ partialo

Iotal dopostition $=6.5 \times 10^{6}$ partiakes.

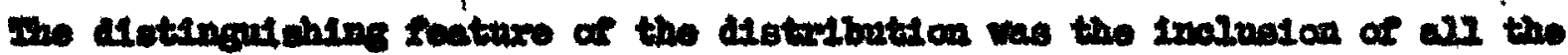

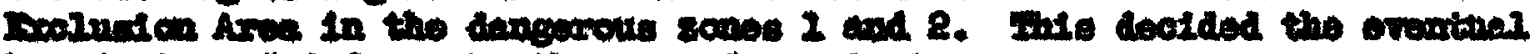
boundarted of dafones by the wes of soeptratore.

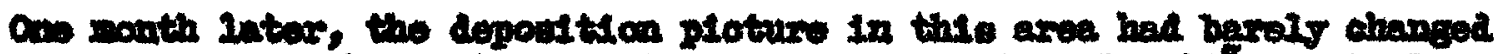

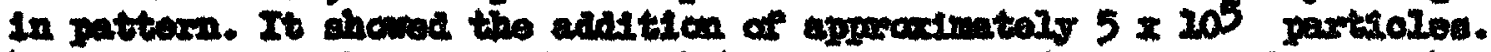

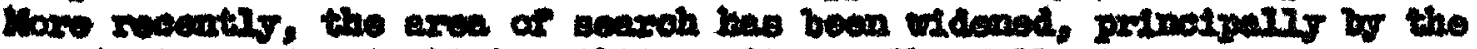

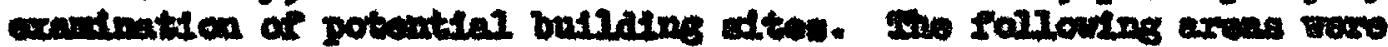

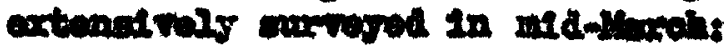

\section{$\sin A$}

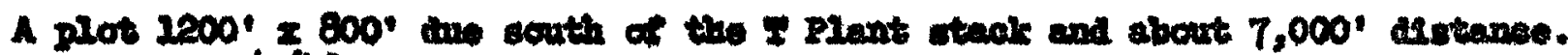
Completed $3 / 9 / 48$

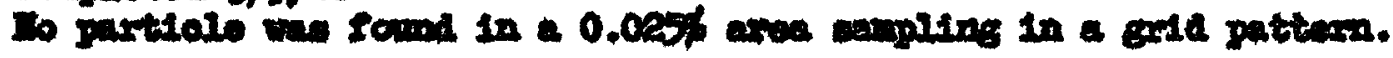

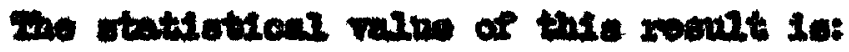

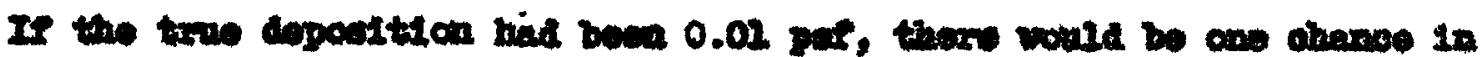

10 of Inieng no pattine.

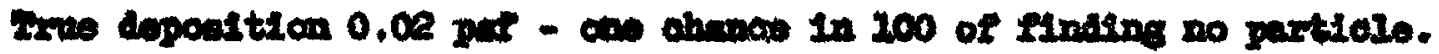

$\operatorname{Arg} 3$

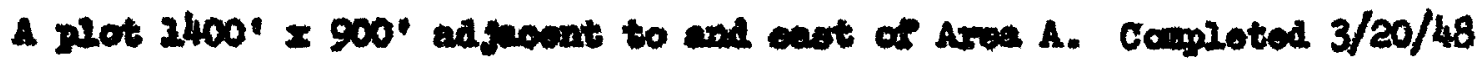

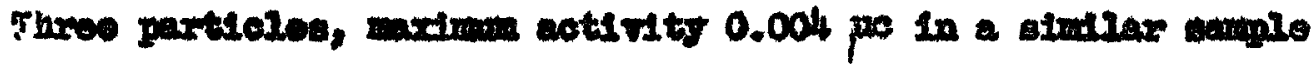

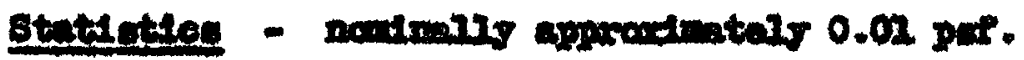

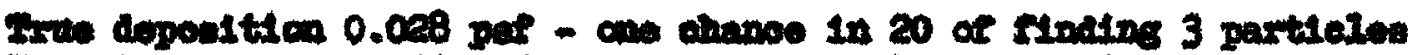

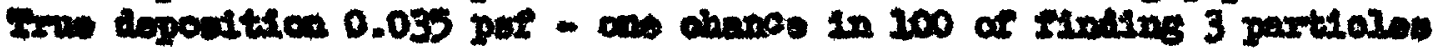
co st the oppostte lint

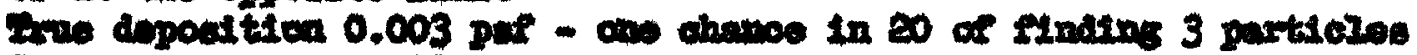

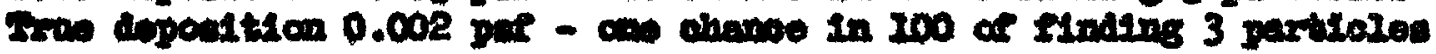

Ax 6

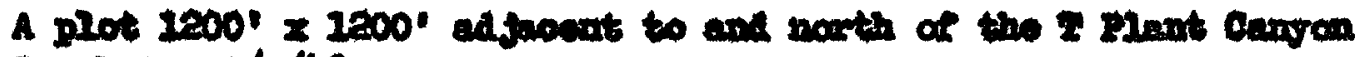

Coingetad $3 / 9 / 48$

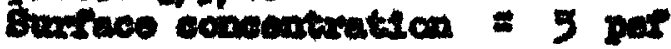

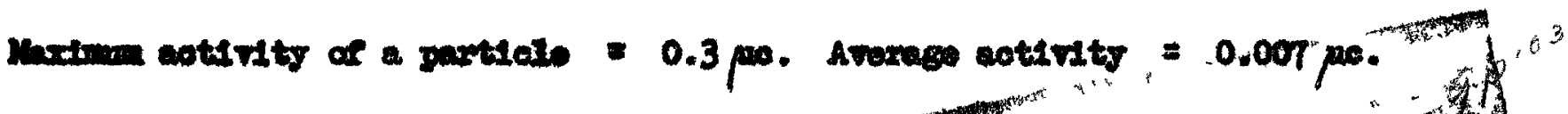

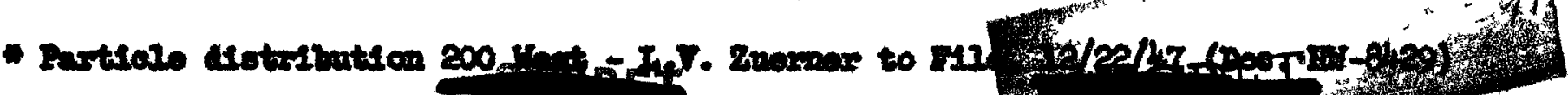




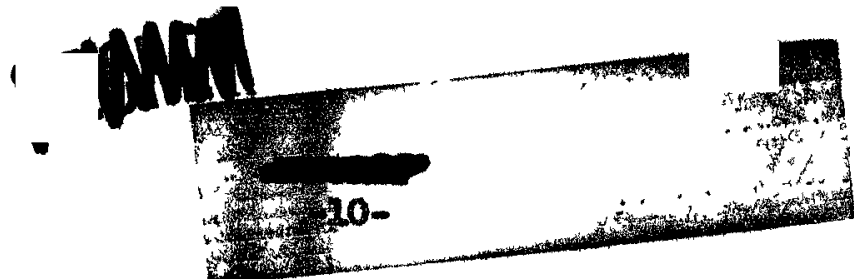

Area D

A plot 400' $\times 400^{\prime}, 3000^{\prime}$ dwe east of the B Plant wtack, at the 1000 tion of the original c Plant. Comploted $3 / 9 / 48$

$\begin{array}{ll}\text { Surface copcentration } & =2.5 \mathrm{par} . \\ \text { Unxelman aotivity } & =0.016 \mathrm{pe} \\ \text { Average activity } & =0.002 \mathrm{po}\end{array}$

Ares $\mathbf{E}$

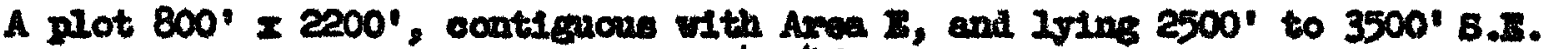
of the B Blant stack. Completed $3 / 20 / 48$

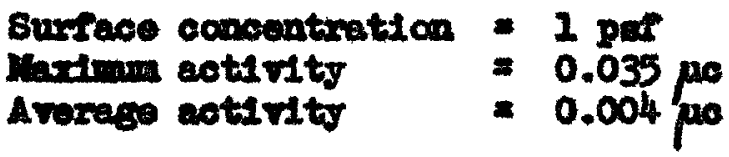

Axea 2

A plot 500' $x 2200^{\prime}, 8.3 .2$. of the B Plant stack, and $1000^{\prime}$ to $2000^{\prime}$ avay. Dite is olowe to neng of the servioing work areas. completed $3 / 22 / 48$

$$
\begin{array}{ll}
\text { Burfuce concentration } & =1.8 \mathrm{per} \\
\text { Ineiman ectivity } & =0.2 \mathrm{po} \\
\text { Averwgo activity } & =0.069 \mathrm{pc}
\end{array}
$$

\section{Arca $a$}

A plot 1100' $1600^{\prime}$, due vest of the 8 Plant otack, and $1000^{\prime}$ to $2000^{\prime}$ Irom 1t. Completed $3 / 18 / 48$

$$
\begin{array}{ll}
\text { Surpace concentretion } & =1 \mathrm{par} \\
\text { Inedrum activity } & =0.01 \mathrm{pe} \\
\text { Average activity } & =0.004 \mathrm{po}
\end{array}
$$

Axce 5

A plot $3500^{\prime}$ x $2000^{\prime}$, E.X. Of the B Plant stack, and $2000^{\prime}$ to $5000^{\circ}$ antay. Coupleted $3 / 17 / 48$

Buxtace ocnoenteration = appreatinately 0.003 paf No activity in excoes of 0.004 pe.

\section{Area I}

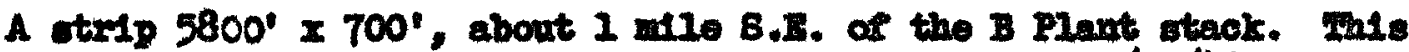
parvileto the south alde periut tor road. Comploted $3 / 19 / 48$

Suxpece concentration $=0.04$ par

Wo activity in excese of $0.004 \mathrm{po}$.

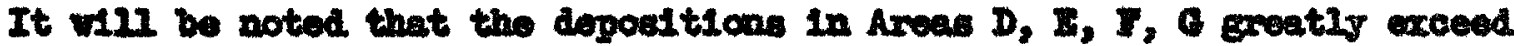

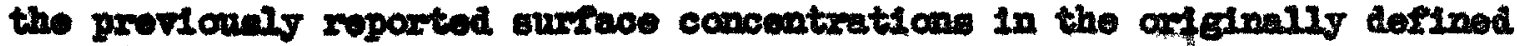
2owe 3. There 1s scone evidenoe that apparent increase of cascentration

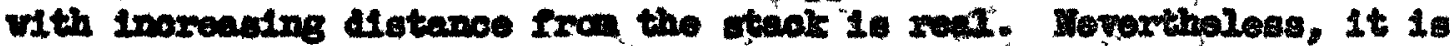

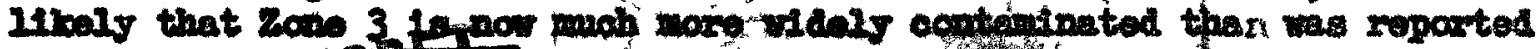

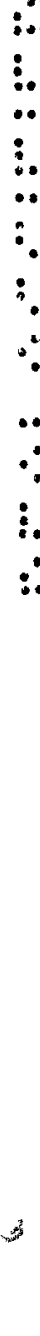




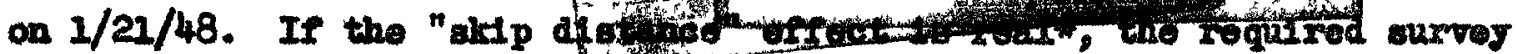
progrum reachos a magnt tude weyond that orlginally contenplated. It vill cocupy at least 500 man wooks. The ourrentis avallable force is 5 mon; by borrouling of manpower from other doparments, and by unergency purchase of Instrwants, the force cen hardly be brought to more than 35 . A ocmprehenel ve survey thus camot be recorded in 1008 than 3 monthe, by whioh timo the overall picture may have changed completely. Radical corrective measures at scarce are clearly indicatod.

AII the above eurreys have been conuldered in terms of detection by Celger countere. It is known that radloeutographa may ahow many more particles then can be found by counter mpthods. The reletive detection coofflolont is a function of the exrece concentration, minly bocause the standard counters used cannot differentlate betwoen closely spaced pertioles, and the radiation from weak particles is roadily obsolured by strong nolghbors.t* As now operated, the following coarfieleats apply:

Burface density br count ex

$$
\begin{array}{r}
15-30 \text { par } \\
8-15 \text { par } \\
4=8 \text { paf } \\
<4 \text { par }
\end{array}
$$

Detection coefrlofent for redionutographs

\author{
12 to 20 \\ 5 to 12 \\ 1 to 5 \\ Approximately 1
}

Whothor the woak particles detected by refined nothods are hazerdous is not known. As an outright euess, the writer ls not unduly concerned about ectivities leas than 0.01 no each. Horeas the carliest particle date ooroxed the range 0.1 we to 3 ue, ourrent detection nothode go down to $10^{-3}$ no, by countors and porhaps to $10^{-4}$ no by radioantographs. It 18 Inteasible to correct the earis work to the standards of the now: the uteady ingrovenent in technt que should not be orerlooked in a revien of the data.

\section{- Rate of deposition of particles}

Atterpte have been made to eatablich the rate of deposition by the exposure of rugs, and lator of elass oloth ourfaces for intervals of about ono month. These cetching ourfeces were soreoned from the wind action by the ouperpositicn of expanded netel mokh, and supported 3 foet abore the ground to alnialse rooulpt of particles Irou adjecent ground. Although elinination of vind transport is not claimed, the reenits should eive the ocmbined dopoettion from the otack, plus waterer is plolrod up from the ground and rodopositod. Ont1l recently the deposition by this mothod was found to rall into a pattern quite similar to that ohom by the total deposition to date. Zones of maximum deposition rate showed 4 to 8 par per wonth. Daring the month of Deceniber 1947, the Integratod deposition In the 200 Eest Area Zones 1,2 and 3 wa 650,000 particles by this mothod. It has protiously been shown by aubtraction that 2 million particles appeared botween $11 / 28 / 47$ and $1 / 21 / 48$. It is reasonablo to aseums that one million appeared in December. Tho two approaches are therefore in good agreemont, within tho eccuracy Iint ts of eech procedure.

* "Bpot contenination on potont1al builaing altos "Z.M. Parker to W.P, Overbeok 3/10/48 (Doo. Bi-9241)

* Counter dotection could be Improved by placing unotal grid over tiv

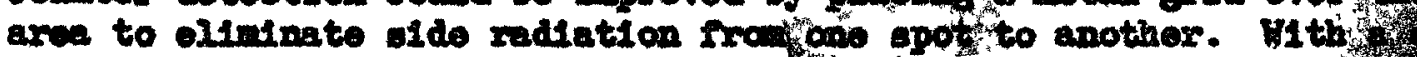

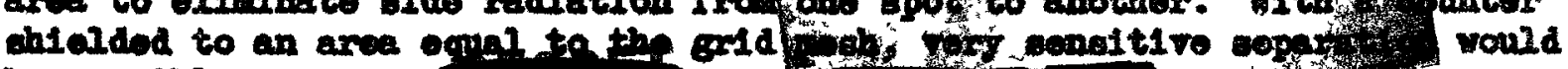
be posetble. 


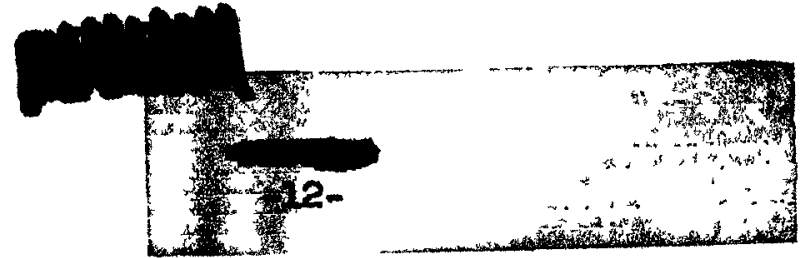

The Itriluence of the 200 zact Area fan and duot change has boen studiod by obderving the deposition rates on catchers for the mointh of December 1947, and for a ointiar porlod bogdming $1 / 15 / 48$. In the Zonos 1 and 2 , the total deposition of perticles in these two perlods was of ther the same or not roducad by a factor as mach as two. The change did oliminate

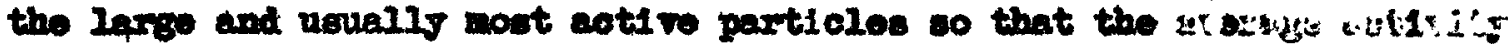
of deposited partiolos foll by a factor of 5 . Onis in the apperent mall roduction in the mmiber of enill particles does there eppear to be scmo

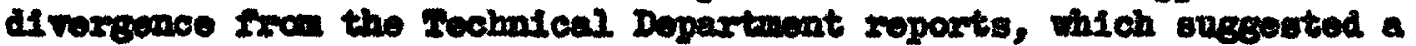
wnoh mors onbetantial roduction. In late Jobruary and earis Karch a sorion of collections wes made in a line extonding dne north fram the T Plant steck. Fese olearly show the aldi-distance, or increace in concontration vith distanoe, and thus substantiate the suepl 100 of this frow the total deposition date.

$\frac{\text { Distance from Stack }}{\text { Peot }} \begin{array}{r}500 \\ 1500 \\ 2500\end{array}$

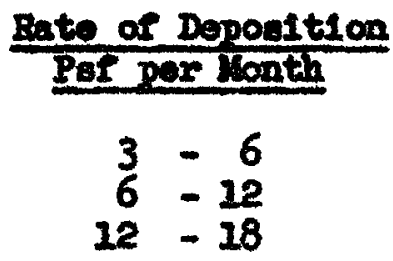

\section{d. Conoentration of active partioles in the atmosphese}

This has bown moarnxed by suction at 3000 ofm. through glass cloth filtors In the expected location of maximm concentration in the B Plant.

Iyploal resulte wore as follows:

\begin{tabular}{|c|c|c|c|c|c|c|}
\hline Date & $\begin{array}{c}\text { Dhasution } \\
\text { Eowne }\end{array}$ & $\begin{array}{c}\text { Partioles } \\
\text { No. }\end{array}$ & $\begin{array}{l}\text { Activity } \\
\text { Bange (ne) }\end{array}$ & $\begin{array}{l}\text { Concentightion } \\
\text { * per } 10^{6} \text { oft }\end{array}$ & $\begin{array}{c}\text { Activity } \\
\text { Concentretion } \\
\text { ne/21tex }\end{array}$ & Bomarise \\
\hline $1 / 76 / 48$ & $\begin{array}{l}5.5 \\
168\end{array}$ & $\frac{2}{6}$ & $\begin{array}{l}0.01-0.015 \\
0.005-0.02\end{array}$ & $\begin{array}{l}2.2 \\
0.2\end{array}$ & $6 \begin{array}{c}10^{-9} \\
\times 10^{-11}\end{array}$ & $\begin{array}{l}\text { pre-fan } \\
\text { chang }\end{array}$ \\
\hline $\begin{array}{l}1 / 27 / 48 \\
2 / 10 / 48 \\
2 / 27 / 48 \\
3 / 12 / 48\end{array}$ & $\begin{array}{l}188 \\
240 \\
372 \\
341\end{array}$ & $\begin{array}{l}1 \\
1 \\
50 \\
56\end{array}$ & $\begin{array}{l}0.004 \\
0.035 \\
0.001-0.03 \\
0.001-0.01\end{array}$ & $\begin{array}{l}0.03 \\
0.023 \\
0.75 \\
0.9\end{array}$ & $\begin{array}{r}4 \times 10^{-12} \\
3 \times 10^{-11} \\
2.5 \times 10^{-10} \\
1.8 \times 10^{-10}\end{array}$ & $\begin{array}{c}\operatorname{Pan} \\
\text { ahanged }\end{array}$ \\
\hline
\end{tabular}

W1th the exclusion of the mort rwn, the highest particlo conoentration corremponde with the expectation of a man inheling one particle in 150 months. If this date could bo ecoepted, at face value, the urgenoy of solution would be removed. It should be noted that:

(1) Inow is now mach 10as oertainty about the area of maximm conecentration.

(2) The glase cloth 111 tor is probably a poor catcher of very ginill particlos.

Othor alr collections by mane of the familiar Big Suckers have ohown onl cotive duat, not rescivable as partiolos in a total eample por 180,000 ort of est. 


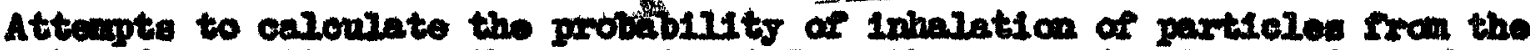
rate of deposition on the ground and rrom the rato of eateston fros the stack. Thoes dopend on a knowhedge of the rato of fall, canputed to bo 1 foot por seo. for a particie of radivs $0.03 \mathrm{~mm}$. In zonos of hoery concentiration thees mothode Ied to inhulation ratos af about ono particlo

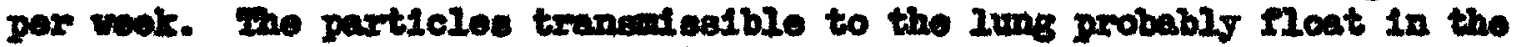
air or at least have $10 \mathrm{wer}$ affootive terninal velooities. The quoted Inhalation rato ie pxobebir not consernative. The vidter is mable to nocosel2. this with the data Iron the Iarge alr eamples.

\section{Bnmary of Soctions 2 and 3}

The active particle contanination was dotectod by follow-up of mall deflations from the normal patten of cchtalination. AII the Iaxpe and mont active particles were exparable by megnotic ecans. The source or at least the prim eoures was corroaton of breck iron dnotwort in the

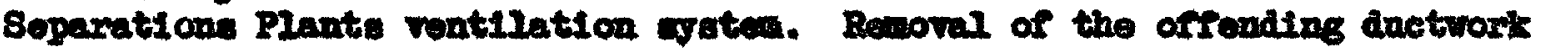
elininated the Iarge particles, but had relativoly Iittle influence on the

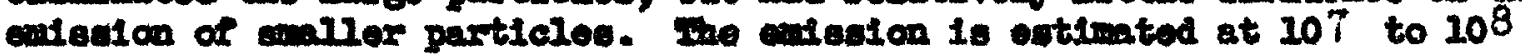

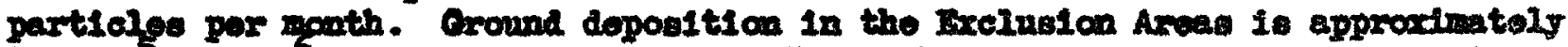
5 × $10^{5}$ to $10^{6}$ particled per ponth. The highest lmown exriece concentration is 50 paf in 180lated areas near the stacks or whore thoro has been obviona wind irift. Whe highest concentretion over an extenat ve axea 10 about 10 per.

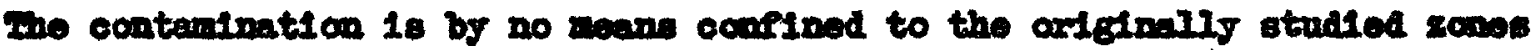
In the Ireluaton Areas. Comoentrattone as hich as 2.5 pef have been found 3000 ' cast of a stack.

There haw been recent indloutions of a dharg inorvase in the muber of particlen on the cround. Hothor this is also to inoreased ealsalon or to

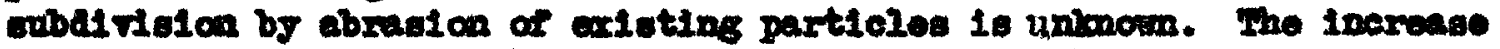
16 estinted to exoeed the adnitted insrease in eldil in dotoction.

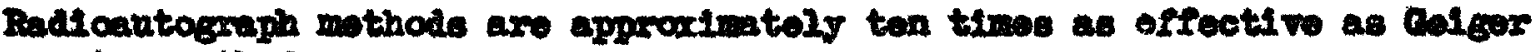
eormter mothode.

the probablo inhalation rate from toots vith collection on Fliters 18 ano pertilole por 150 months. Whis techni quo may wise all rery all partielos. Caloulations indicate an irhalation rate of on per wook for mall partioles. It is not known whother those aro hasardons.

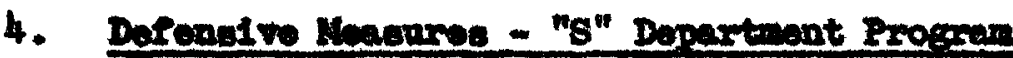

Clowe cooperation botween the "g" Dopartmont, the Treintical Depertmont, and

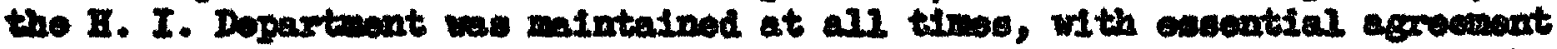

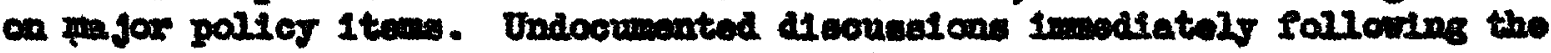
Afecoreng of the hazand ware conoernod with:

a. The foalbility of haring all mon in the affooted areas wour reeplratore;

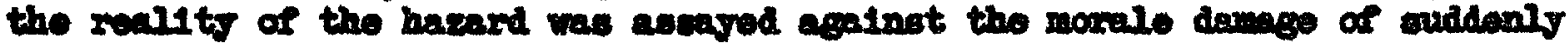
rogutring such protootion

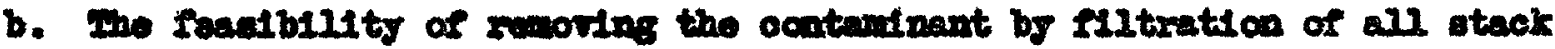
15, Including wah posabilitios as cleaning the stapk 


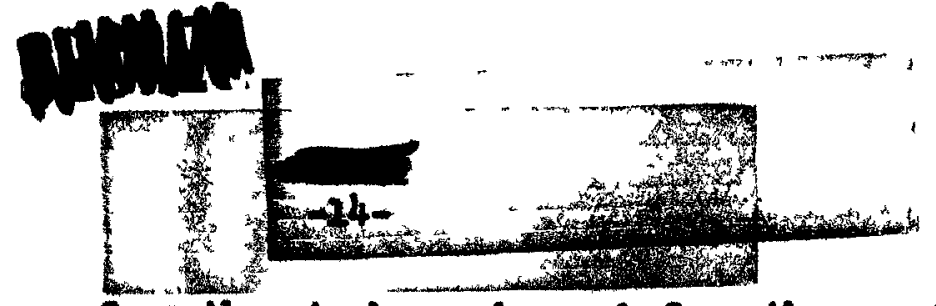

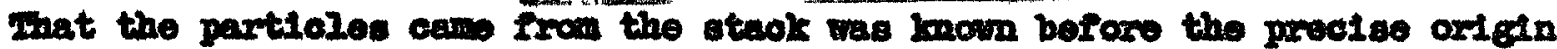
we 1ocated.

The proposed suture reccumondation of the I. I. Departmont for varicus contingenotes was dorinod in the valtox' Doc. In-7920 - 10/30/47. Whis Ineluded taolt agreenont wth the obgeative of Iuxther dorining the hasard, before repplretore woxe requested.

Dosigas to pernit the following Inotallatione were requestod on $12 / 3 / 47$.*

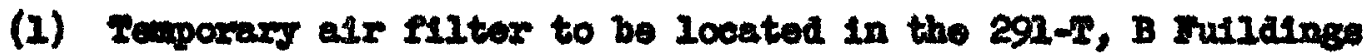
between the crigting fans and otecks, and

(2) A perwanont P1Iter byaten to be instelled in the 291-2, 0, 8 Buildings botween the exlisting fens and now or revised ateoks, the

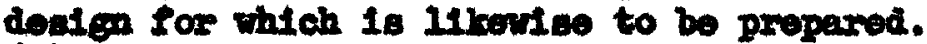

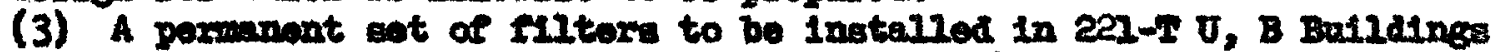
In the Individual cell exhanst ducts and tho $224-F, U, B$ Butldings tent rent piping.

The objectives were (I) To renow all particles ortelnating prior to the

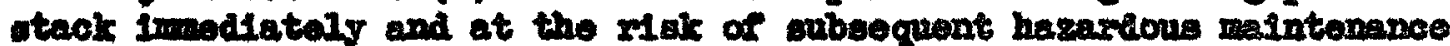

(2) To follor vith a pormanont ingtallation inoluding new atacks.

(3) To filter the alr from cach separate coll of the procese builainge. Ine proposed eotions of the varlous collaborating departmente mexo deflnod In Iine with the abow intentions on 11/26/47.

Bf $12 / 9 / 47$, It hed boen fully roalized thet the prinelpel offonding particles

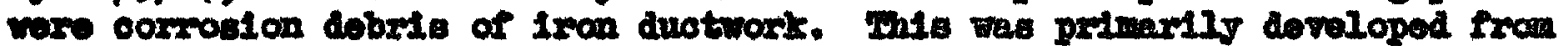
the Toohnical Departaont eampling results, and was enpported by inspoctions

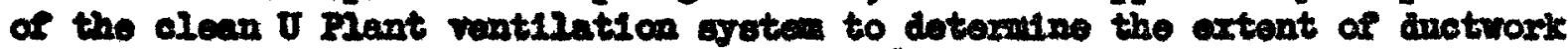

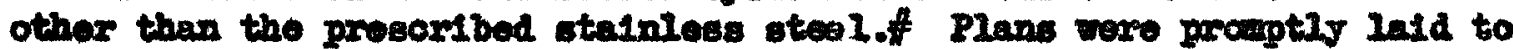
roplece the duct and blowere, because this change could be coupleted in balf the tim and at tivaty-elve percent of the coot of the proviously

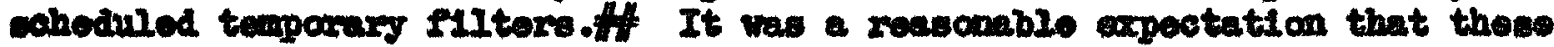
repalre rould remowe the sowroe of the opntaninated partieles, and therefore atnimize or elintrate the noed for flltors. Changes in the applicablo Buppenes code to handie the revieed progrem vere documonted on $1 / 9 / 48$. HIf

In the meantime, the Inpracticability of arfiring at a opeedy factual -valuation of the exleting basart was apprectated.

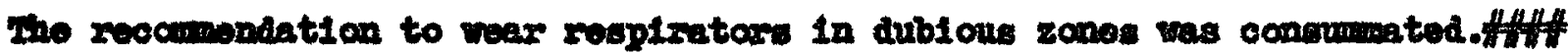
A cheap disposeble unit, the Hartindale Protectite Hak had been Iocated for this purpose. Although it was reoognised that suoh f1Itexs had 100

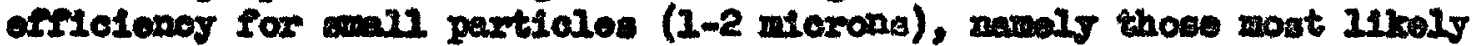
to bo Inbaled and rotainod, there we then no evidence of inportant activity on the mall entit1es. Plans were made to ourves the removed

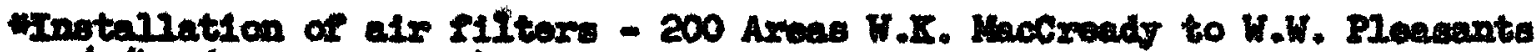
12/3/47 (Doc. Ex-7932)

HDDe. EH -8108

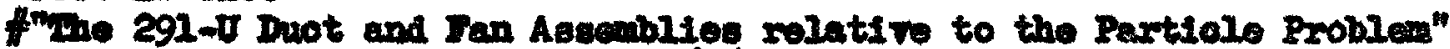

I.C. Hoos to II.I. Mickelson, 12/8/47

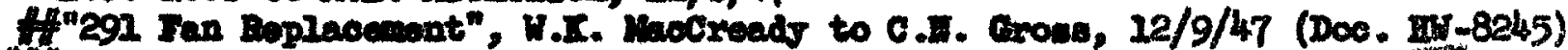

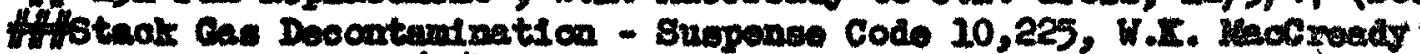
U.P. Orerbeok, $1 / 8 / 48$

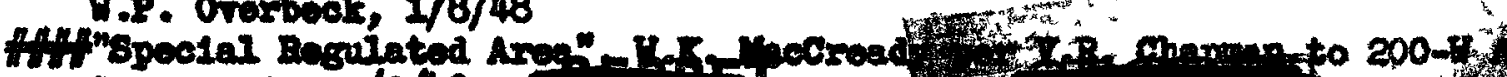

Suporritaton $I / 2 / 48$ 


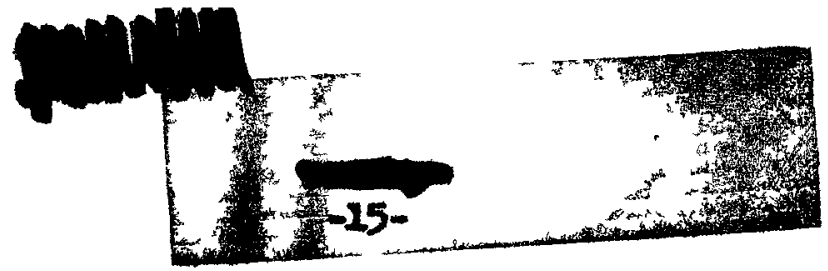

pads at the ond of each vorivilay. Init proteotion we applied throughout

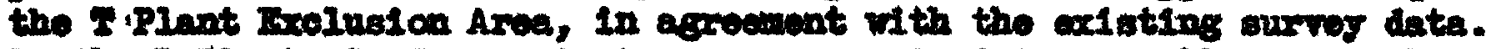

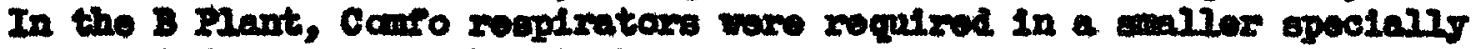
rootisleted gows near the staok.

The curront plan of action was darinod in a joint wenorandun of the

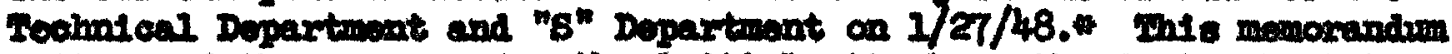

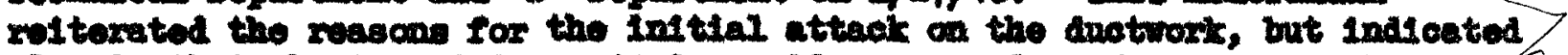
deariy that the immodiate partiole problen was only a fraction or tho

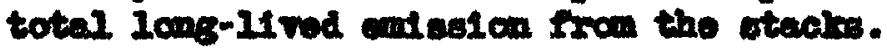

A study of atops to eliminate the puimary mite or aroplet contanination

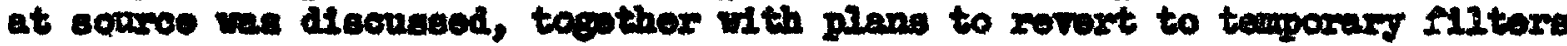

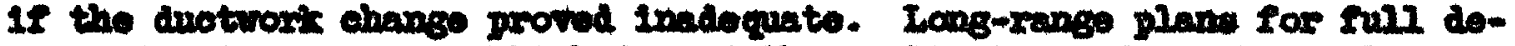
contamination wene establishod, end the appilication of aimilar ecintions to now coparations invtalintions discused.

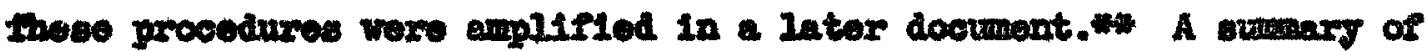

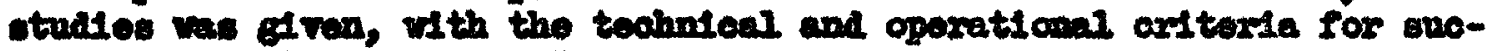
ceosin deccentanination. Intended action was doflnod undor the following hoadings:

(1) Projoct Doginoorlns Doparkmont to procuro and/or fabrleato and inotall test unite, inoluding one lestrostatic pracipitation

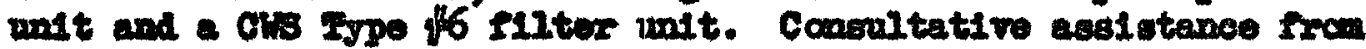
the rallex Carporation to be sollcited.

(2) Irchinical Doperbusit to furtify or improve prosent semplins mothods. Couraltative gutdance of Dre. Langulin and Sohnefor vore to bo obtalinod by Ioohnical Dopartanent and I. I. For this, and Ior an analytical study of the process offluents.

(3) Considaration of cections that could bo turnod over to off-atto croups. Inability to ruproduce soparations plant rentilation alr

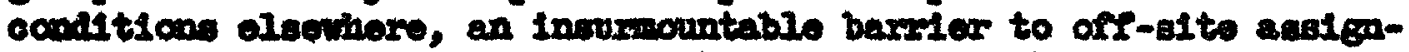
wont of current 10001 problea. Tho funotion of the Alr Roduction Company to ongage in long-xenge, overall studles.

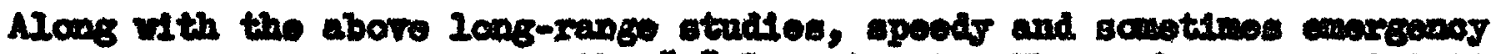

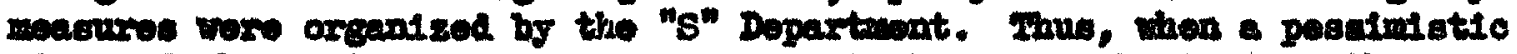
vior of the contimed eppearence of particlos vas oubmitted by the writer on 3/19/48, temporeng I1Iters woro doalened, rabricated and Inotalled In each cell of the B Plant Cangon by 3/22/48. Bintlarily, when the anrface conoentrattions in Aree $I$ wore amoouboed, steps vero talion to

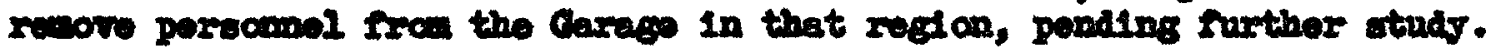

Considorsble attenticn hs. boen focuseed on the contemination of proposed atter for sutwre expantion, and ourvoye of the Areas A, B, C, D

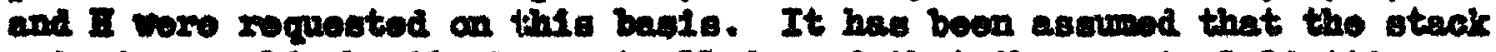

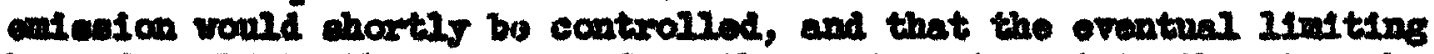

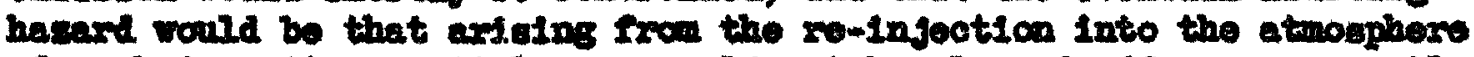

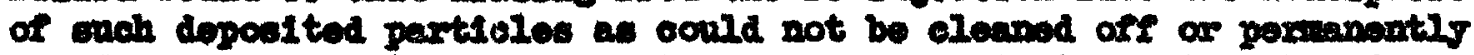

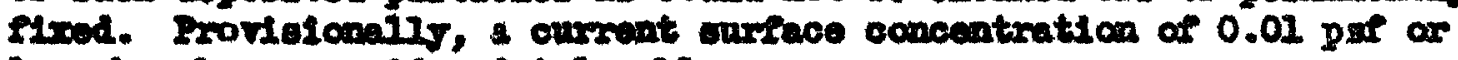
loes has been constdored tolerabie.

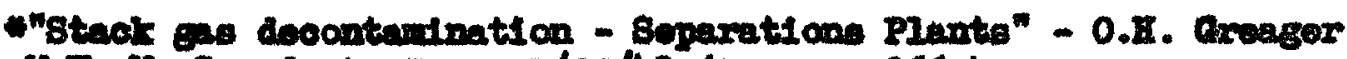

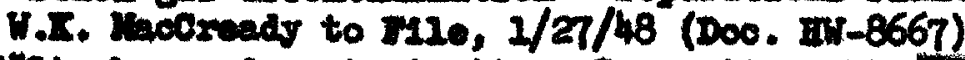

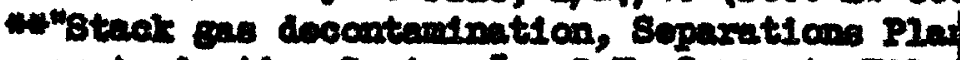

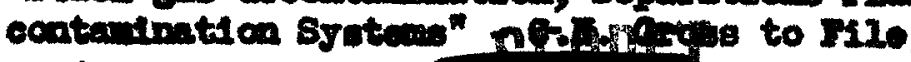




\section{$\operatorname{mat}-\mathrm{IL}$}
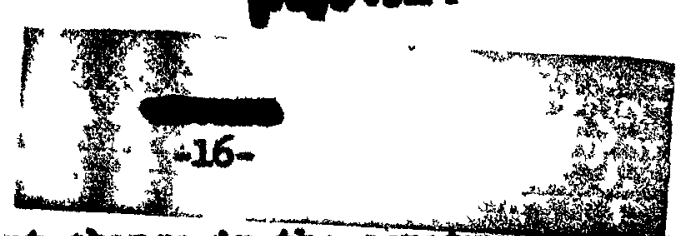

III -9259

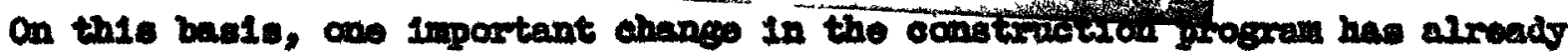

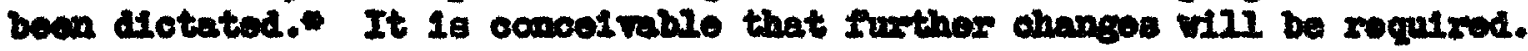

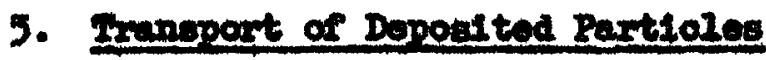

Mile it was realized at the atart of the investfgation that doposited particlos wast bo mowed by the agonoy of winds, zein, thormal curronte,

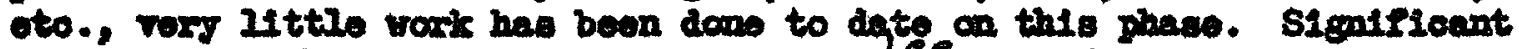

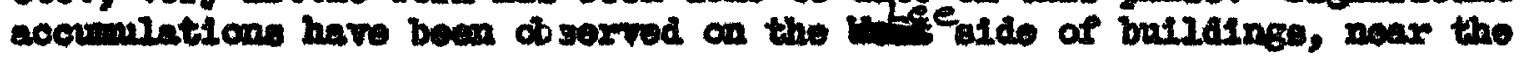
otalus of dosert plants, and even in ratural sallice.

The cetahing axreces to moecure doposttion wore so doslenod to minimise vind tranoport of particlos frem the cetchor framos and to arotd the traction 1 cad carriting alreedy doposited particles.

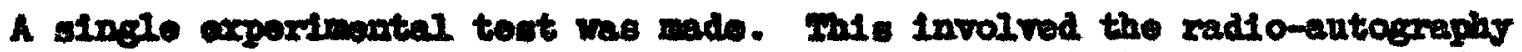
of 10 square feet of desext anxfece, an exposure of the groumd to vind for 7 days, and a ropeat radicantograph in regleter with the fixat. The inftial toet showed 62 particles, of unich 47 romined. Ho particlo

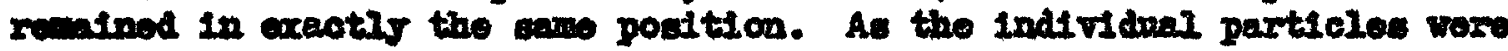
not distinguithablo from each other, it 18 smpoestble to stato how far cach woved, or In the extrems case whether eny of the 47 realdual

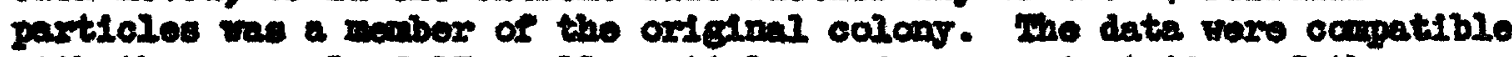
vith the remoral of 15 cmall particles and a ro-orlentation of the zenatinder by inohos only.

Fortultonaly, the wind blem abnost exclusively frem the northerest throughcut this poriod, with an average voloolty of $6 \mathrm{mph}$, and an ummal poens

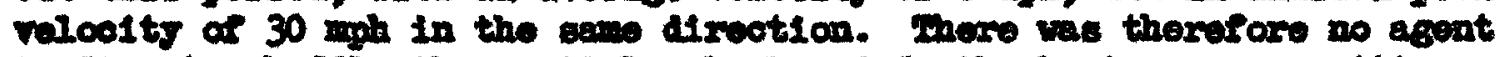
tooding to shnerio the partioles back and forth about a moen postition. since the behariour of depoested perticles 18 expocted to set the roaldunl 2inft an hoelth arfoty in the areas, the otudy of the problem has been agsienod to Dr. P. 2. Church, Hotoorological Conoultant. Io was inflted to consider: wis

(1) Now fart the relevant particles can roll on the cround

(2) Bow hich they can Ines

(3) The poestble concentrations et lovele at which they might bo broathod.

(4) The maximan deposition at dietanoes up to 50 miles.

Dr. Churoh was poesimietic about the feaelbility of anowering those pointw, vithout cutensi vo expoximontation at Benford. areliable on the experimontal trangport of eand exelns, (Institute of reteorologs, Univerelty of Chicugo), the problems of uind veloetty at

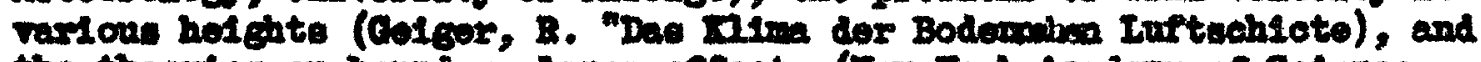

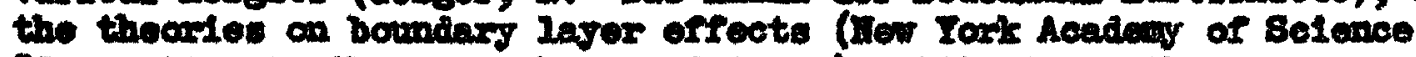
"Conrestion in the Atmooghore and Decen). Dilution with increasing

- "Iocetion af Rodex Dost Ontt", N.P. Orarbock to Carlaton Shugs, 3/5/48 (Doe. Bit-9091)

* "Proposed Problon for lloteorologioal Consurtent", M.M. Parker to W.I. Macknady, 3/21/48 (D00. nt-9170)

" "Beport of Intooralogical Conmitation" P.I. Chnreh - I.K. Pariner 3/19/48 (Fot jot doovmanted) 


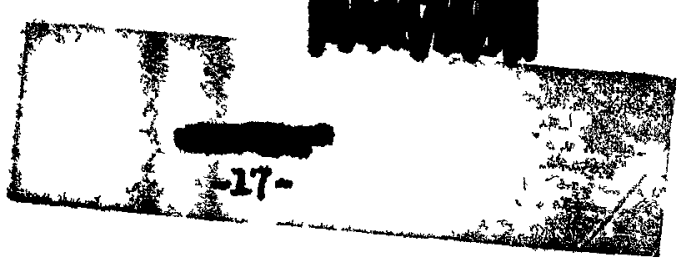

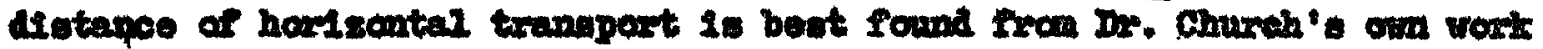
at Eaniond.

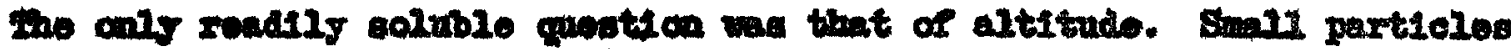

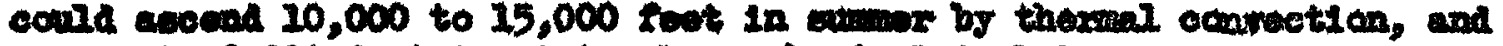

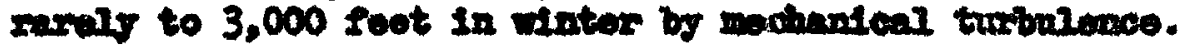

The coumitant was of the optus on that offort shonld bo placed co at-

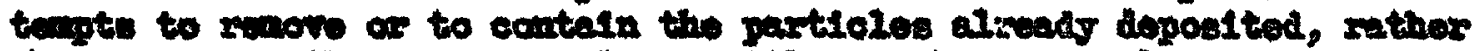

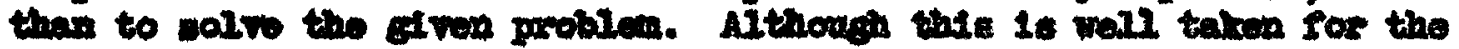

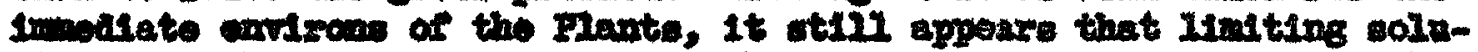
tene All have to be songht. If the date of Beoticne 2 and 3 of the

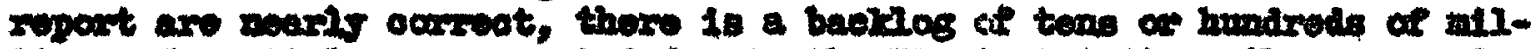

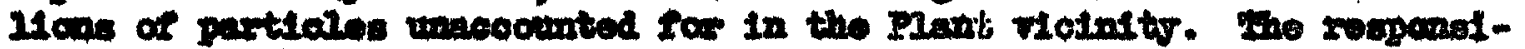

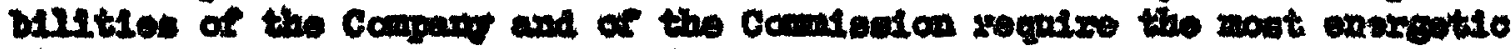

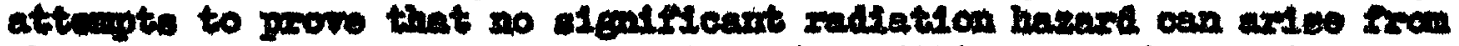

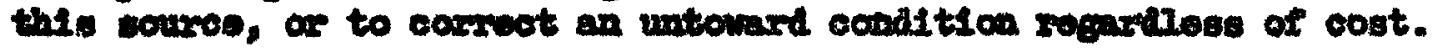

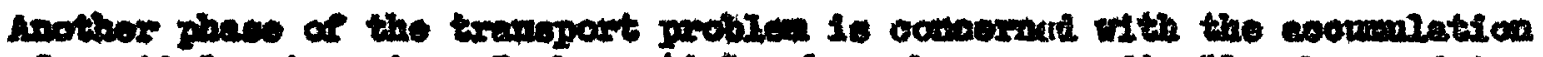

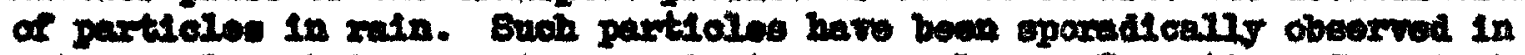

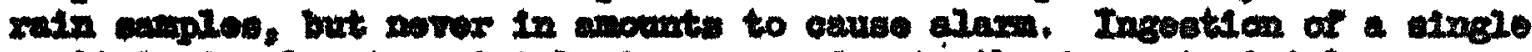

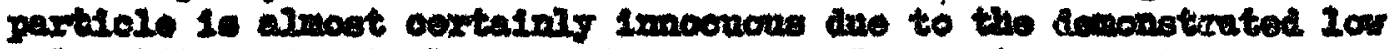

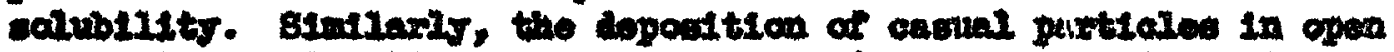

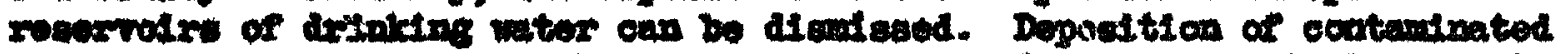

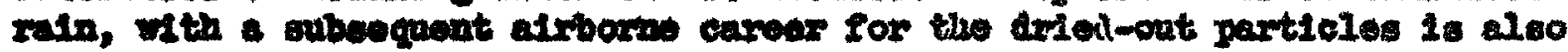

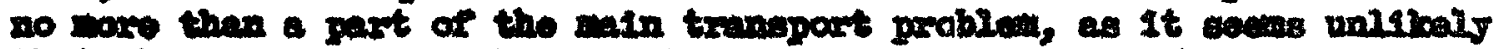

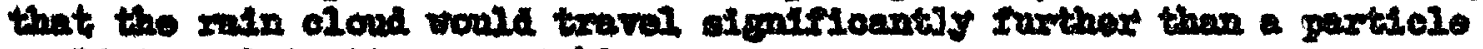
could trevel in 1 to ow right.

6. Degun or simetion of doponstee rastiolos

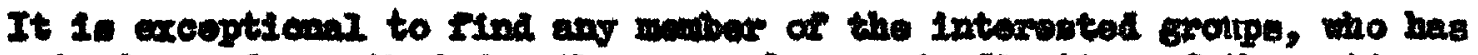
not adranoed a mithod sor the removel on cafe fixation or the eotipe

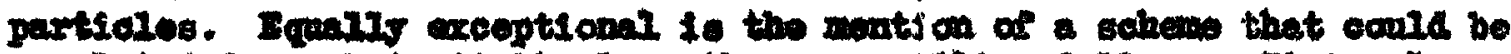

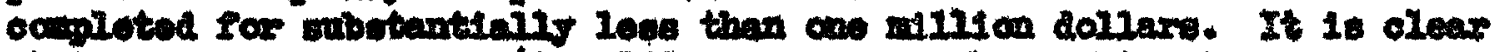

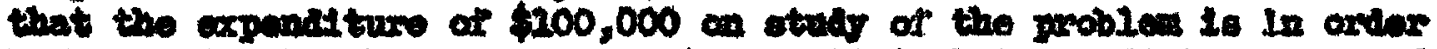

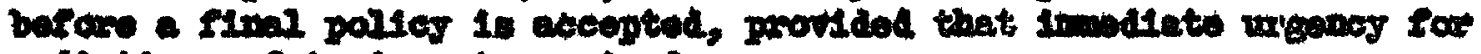
sadiation eafoty is not roquinu.

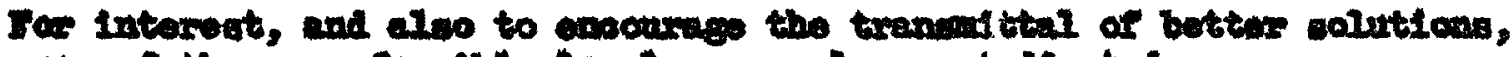

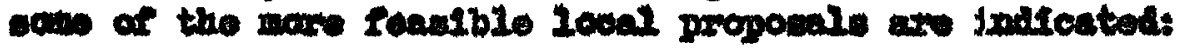

\section{Demene}

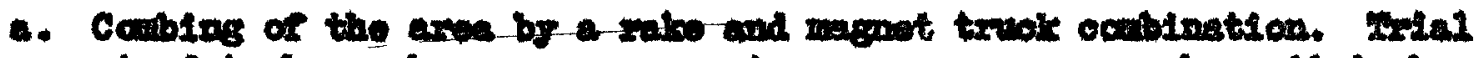

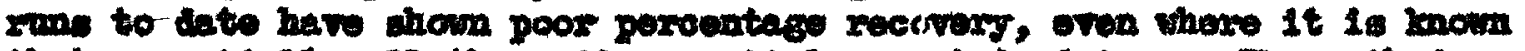

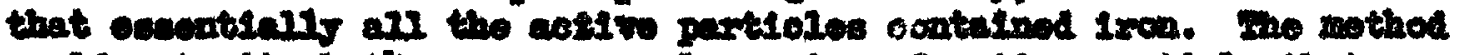

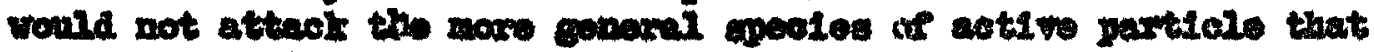
wers best.

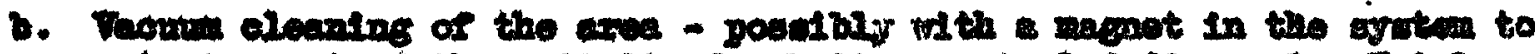

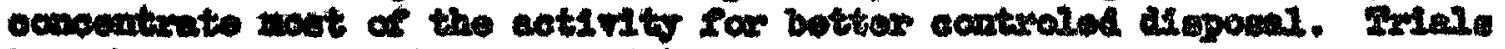

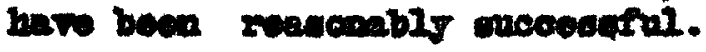

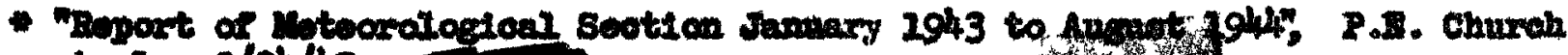
at. $3 / 24 / 450$
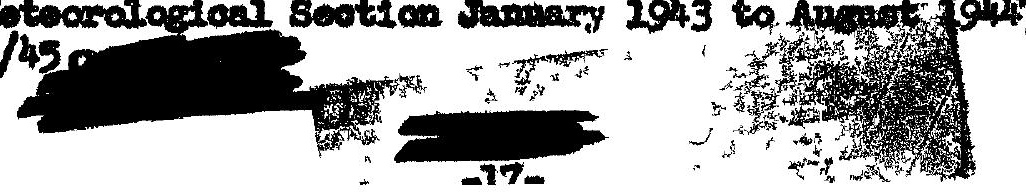

$17 p^{103}$ 


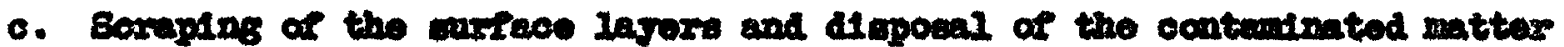

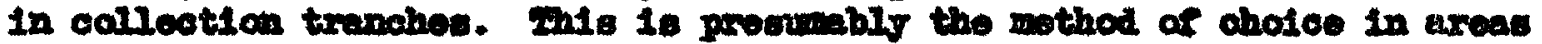

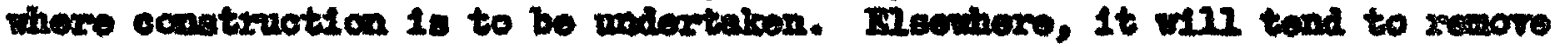
tho natural protoctive harrlers, and thus leav an perticles, not specess-

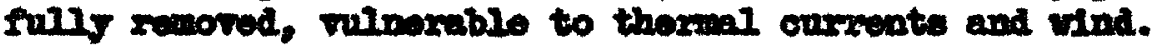

d. Biologicel remoral - the planting of a erop motabolically attruotivo

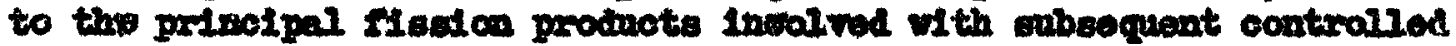

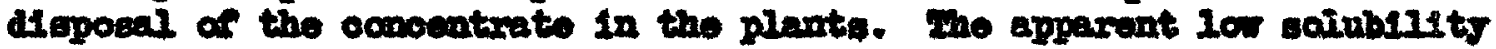
of the activity from the partiales contra-indioates this approwin.

\section{Plontion}

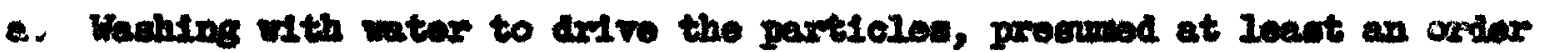
of megnithde mallex than adfecont cand Grains, into the interotices of the vand. Accorting to Dr. Churoh this would ofPer a high dogree of

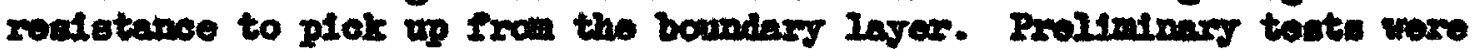
Aleappointing, but the extemel vo teat program outhlined by Dr. Cuwnoh wey ectabliah optinim conditions.

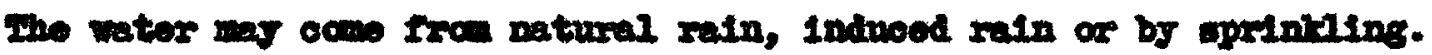

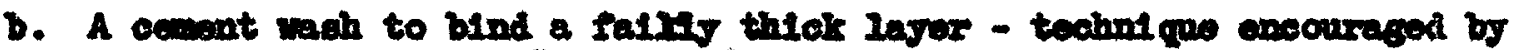

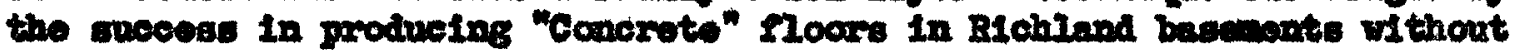

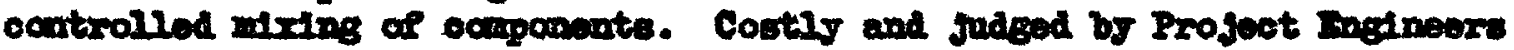
to be a poor Mak under the covere temperature conditions of the denert.

c. Contimod votting of the surface, oven if vater cannot ar1 to the particles dom. Iny alter the boundary lajer conditione in the

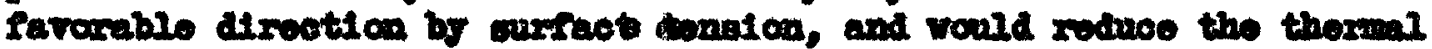
gradiente leading to updrafta. Contly, and not a pacmanont sointion.

d. Road ofl as a bindor. Costly, posaibly a P1ro hasard, and would ill cxioting rogotation, thus doervasing natural proteotion.

- Sodiu allicate or etimilar chentoal Eindors.

f. Ranting of crese. Reported to be a most apfletent rotainer if

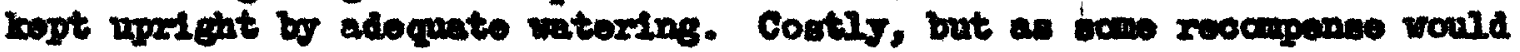
ingrow the amonitte of the dosort Plants. The area cooling arfeat

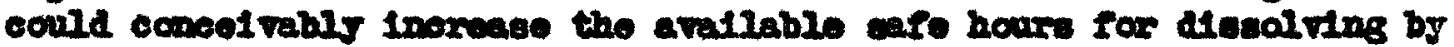
elinination of thesal up-drafte - a valnablo charactexsiotio with a hoats production sobodulo.

6. Hind broek - Ioge, telephone polos or the lile distributed ower the eround, coupled wth perialle vaounm oleanor coulecticons from regtions where the particles would acoumatate.

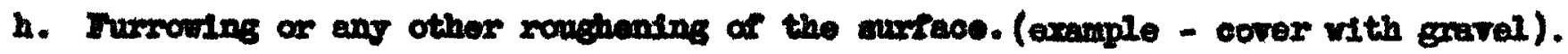

Sumar of Seotions 4,5,6

Protection of all pessocmel has boen aseurad by rhaterer mothod reguirod, itthin the Iinite to vitoh the havaris are malerstood. An early start

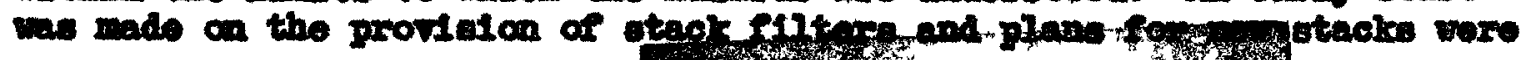
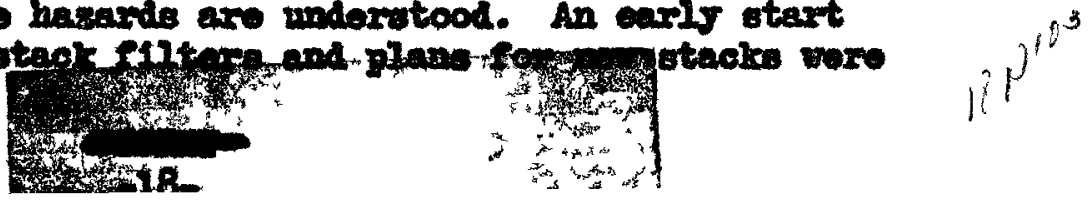


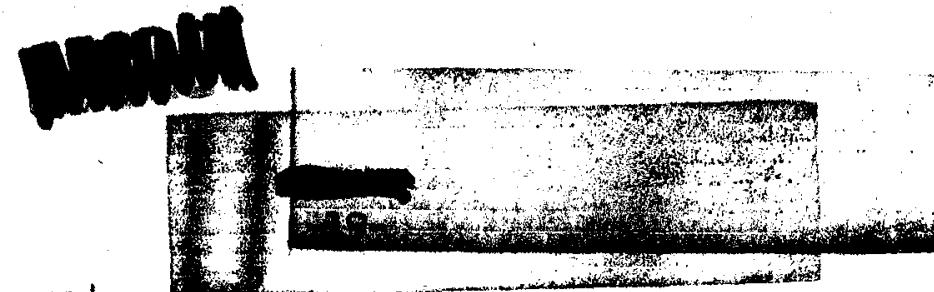

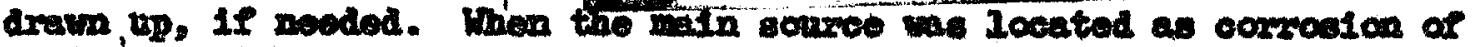
ductroxk, plens rove changed to ockroet this condition firet. Althoigh,

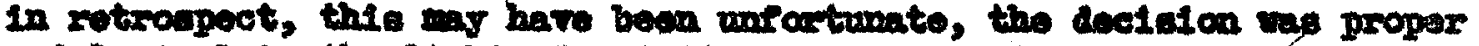
and logical in the light of exteting on procurablo loowledgo.'

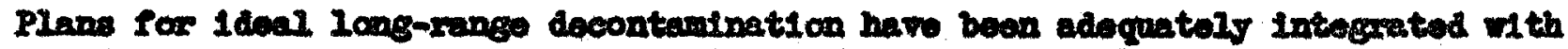

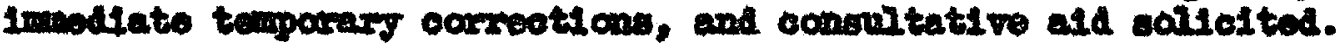

A program has been ande for the invertlention of the tranoport of depoutted partioles, judged to be the realdual harard in the Plant Aroes, and pro-

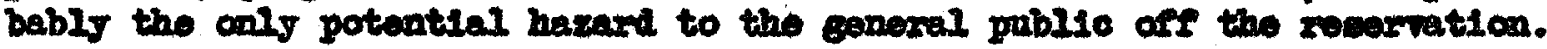

Irthods for the romoval of Ixation of the doponited partiolos are dorm uribed.

7. Chemical, phralcal and allied stadies of the eotive partioles

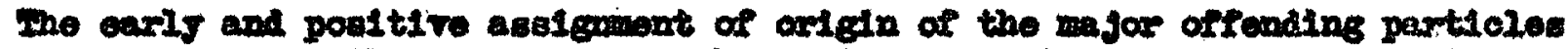

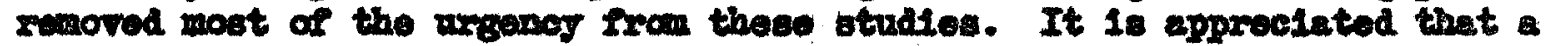
roxy thorongh stedy of the process orlinents is ultimately required. The

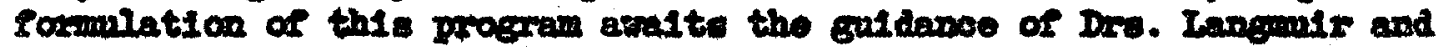
Babastrer. A bxiof roviow of the exploratory woric is inoluded hero. This will be more fully docmiented in a fortheonlng report by R.C. Thorburn.

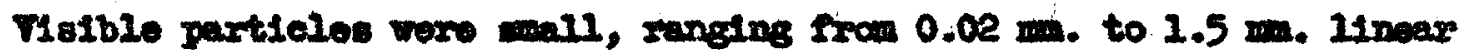

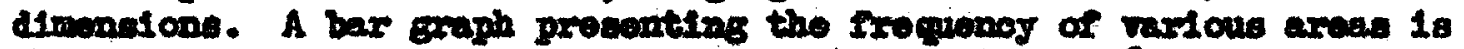
bown, besed on 111 opooks. An area dibtribution of 67 mallor epoolv is

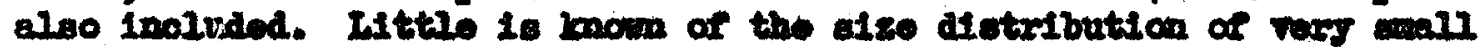
spockes.

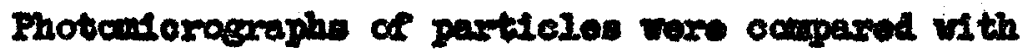

(1) Buet rron dvetworis in the 0 Plant ventilation ayoten

(2) Cenont and bxiokwork from the C Plant oteck

(3) Amphalt paint frou the otook

(4) So12

The eselemeat tio epeoled 1 vas talerably continelng.

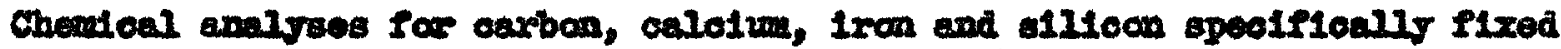

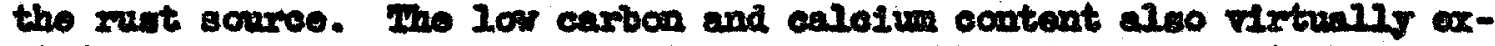
cludes the stack propor as a pribo source. This is important, becanos

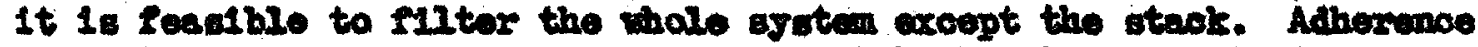

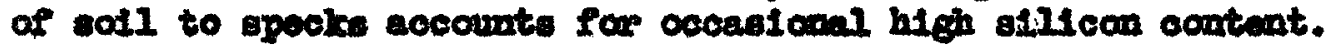

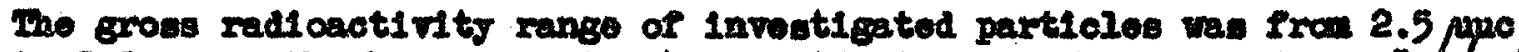
to 3.2. pe, with the conventional simplified interpretation of the "curle" for bota enttors. Alpha particlo activity, prinoipally plutanium, was Found as high as 3200 disintogrations por minute. Thore vio statiotically BI gniflcant comriation botween activity and particlo ourface area. Tho low corrolation coefficient 0.348 has impeded the definition of hastard lintts. Fad this correlation beon absolute it usght bave been foastble to diecount the activity of thoe micron-range particles that could be retainod in the Iung. Where vas poor comrolation botwean rolume and actItity, thus faroring the picture of deposition of spray on frast aurface. 
$\because: 1+$

ㅍำ-9259

Besoras of gmircar ararris

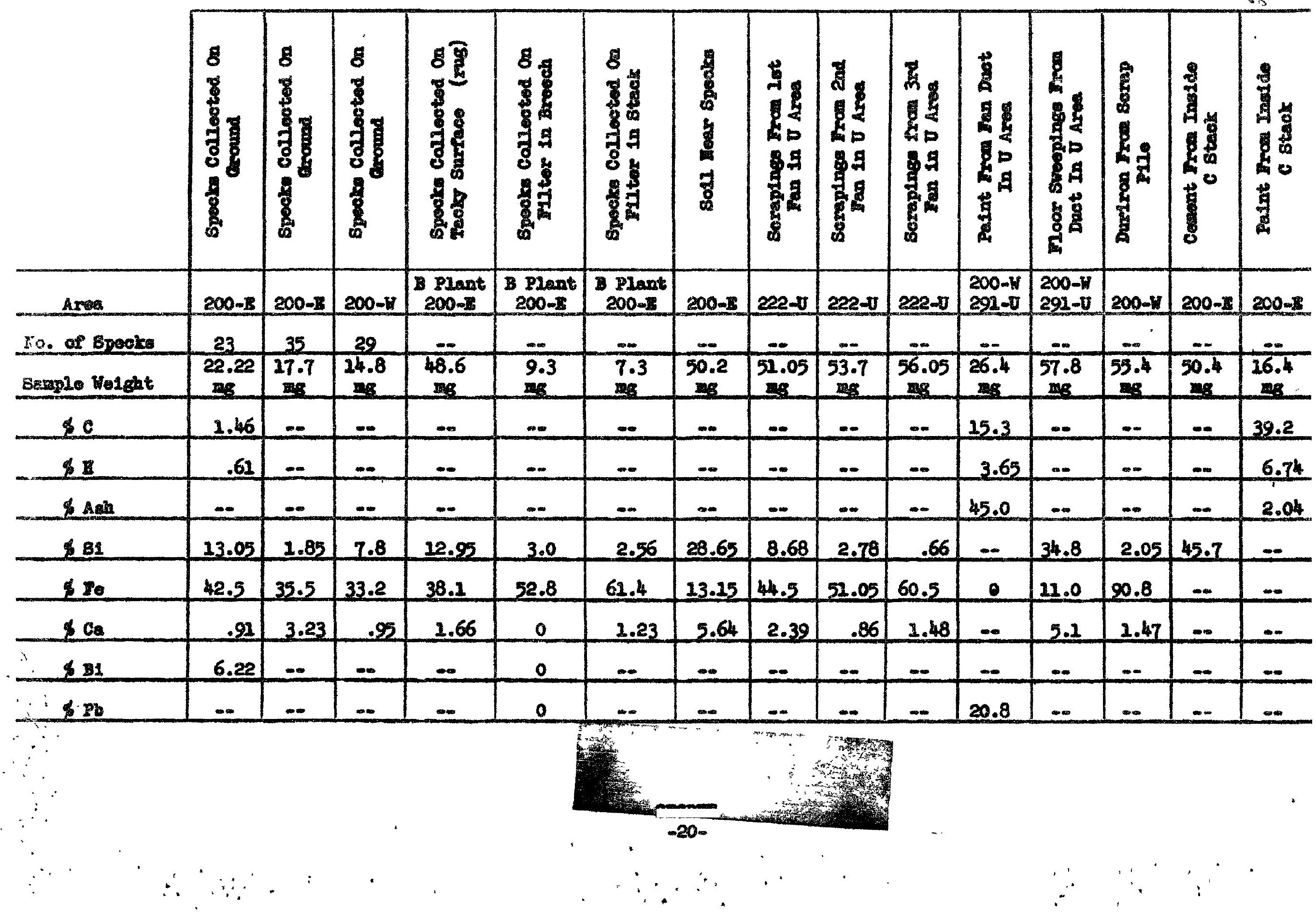




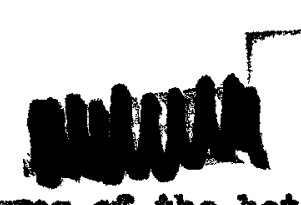
pre esodymitue.

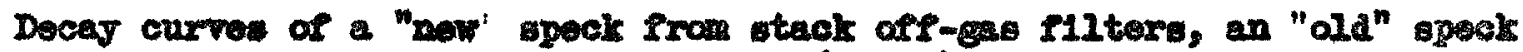
Prom the ground, and of a redicactive (dried) drop fros a hand Inil wero ocapatible with half life of appraximately 250 days, in a 100-doy teat, with evidence of alcuex decay of the "old" speck.

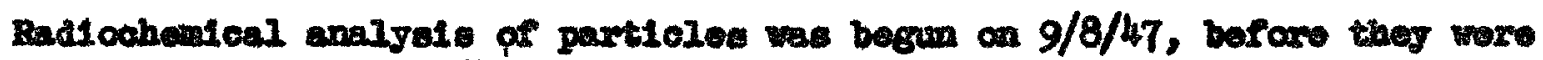
rocogenied as aveh. Inis wes a contributing factor in thair intital ilocovory. Farticles recognized as such wero first assared on $9 / 22 / 47$.

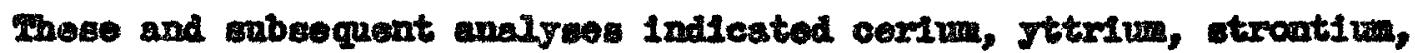

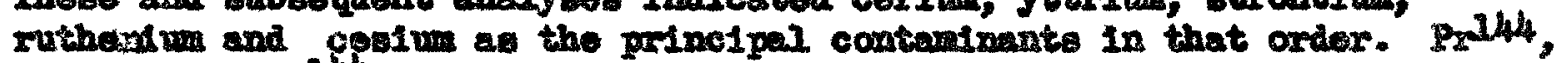
deughter of Col44 is inoluded with the peront, beesuse of the lhort heif 11fe. This prowodyatum vill wake the largeat alnglo contribution to the radiation demage, dno to the high onergs bets particle ent tod. The other predominant pair, 5 r90 and 190 eoperated in the anolyals vithout signifleant crowth during the man. Beck scattoring and oelf-abeorption orrore up to $30 \%$ wero acceptod in those deterninations.

It 1 noteworthy that opocise showing alphe particle activity hav a deto of plntoriun activity to uranive activity of about 20:1. Fis is meh more noarly compatible with the diesolveccantent than that of ang later etage. Did epray from the eoparate disaolver lino cost the already activated particios coming erom the drot? Ifor, if aw, of tho particles could have orielnated in the diseolver orf-ges $I$ ire. At one time thare was moch interest In the "age" of the oultted perticles. Fhe elementary caleulation from the flestion product epoctrvin may bo invelid, due to colective arfects throughout the proceas. Attempts were made to dofine the age from the two avaliable isotople ratios $5 x 90 / \mathrm{sr}^{89}$ and $\mathrm{Ce} 144 / \mathrm{Col}^{2} 4$. The latter falled on acoount of the couplex disintegrition coheme of Prith

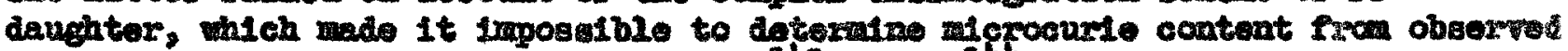
bota disintegration rate. Separated colli and coll4 standards are moded for

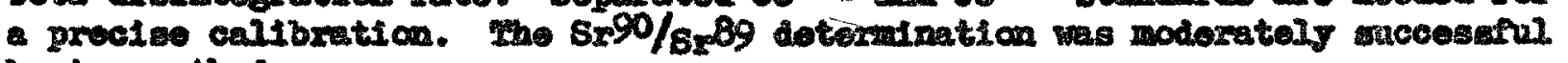
by two nethods:

(1) Doduction of $5 x^{90}$ activity Irom the activity of separated I90 dunghter. Belance of the total Sx actirity aecribed to Br89.

(2) Change in total sx count (after milising of 190 ) with timo due to relatively rapid decay of $\mathrm{Sx} 89$.

Ager betroen 100 and 300 deye have bean reported,

Special tosts made have included:

a. Extraction of fleaton products from epiked Peces camplea, vith dereonestetition of appraximately $100 \%$ ylald.

b. Ixtraction of radio-cerivm ( $90 \%$ yield), Jtbrium (70\%) end strontium (25\%) Ircon splired urino onplos by cralate precipitete. Alternato extraction of atrontium $(90 \%)$ by iron hydroxdids procipitate. phese are the prineipal contaninante to be looked for now, ultivetels, Cel37 night

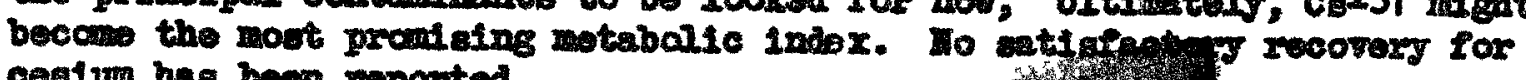
ceslum heo beon reported.

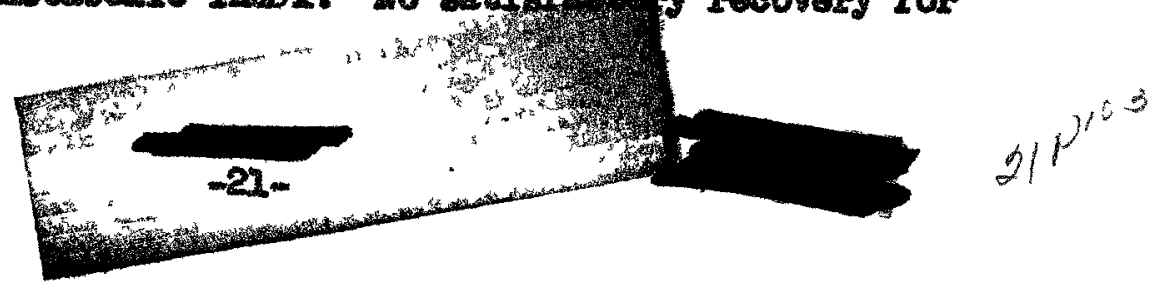




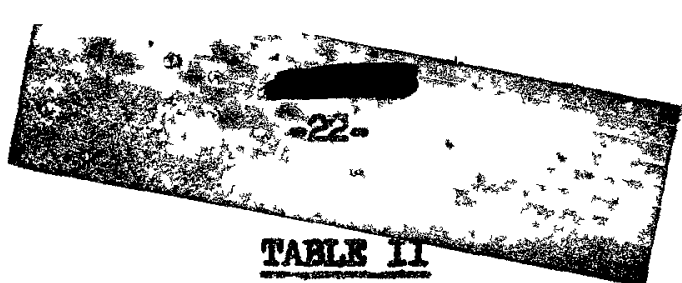

\section{RosuLPS OF BADTO AMLIISIS}

\begin{tabular}{|c|c|c|c|c|c|c|}
\hline Particlo & $\begin{array}{l}\text { "Ola" Perticles } \\
\text { From } 200 \text { Weat }\end{array}$ & $\begin{array}{l}\text { "How" Particles } \\
\text { From } 200 \text { Wat }\end{array}$ & $\begin{array}{c}\text { "01d" Paxtiolos } \\
\text { Mrom } 200 \text { East }\end{array}$ & $\begin{array}{l}\text { "Met" Part1elos } \\
\text { Fram } 200 \text { East }\end{array}$ & $\begin{array}{c}\text { Partiolos Colleotad } \\
\text { From Jtrol Cason } \\
200 \text { East }\end{array}$ & $\begin{array}{l}\text { Part10los Collectod } \\
\text { Irom Brosoh Gaseo } \\
200 \text { Rast }\end{array}$ \\
\hline Iodin & & 6.44 & 3.51 & 3.2 & $4.7 \pm 1.3$ & 7.2 \\
\hline \& Corium & $39.4 \pm 20.0$ & 49.4 & $29.1 \pm 2.0$ & $26.8 \pm 3$ & 18.5 & 28.5 \\
\hline Itsxing & $17.1 \pm 7.0$ & $-\infty$ & $28.3 \pm 9.0$ & 2.0 & 27.1 & 23.7 \\
\hline 1 Raro sexthe ${ }^{2}$ & -- & $=-$ & $\infty$ & 1.13 & 5.98 & 12.1 \\
\hline Strontina & $3.0 \pm 2.0$ & 6.3 & $10.5 \pm 4.2$ & 3.2 & 7.9 & 8.4 \\
\hline Sutheniuge & $2.4 \pm 0.6$ & $=$ & $=$ & 12.5 & - & 13.5 \\
\hline \& crasum & $0.4 \pm 1$ & $-\infty$ & - & $3.7^{4}$ & 0.77 & $-\infty$ \\
\hline OS Colurabiua & $0.7 \pm 0.02$ & $=$ & $0.69 \pm 0.4$ & $=$ & 2.9 & - \\
\hline \$ Barduse & - & - & $=$ & $=$ & 0.1 & - \\
\hline \& seluursur & $=$ & - & - & $=$ & 0.7 & $=$ \\
\hline NIpa Act1 1 ty & & & & $\sim$ & $-2 \cos x$ & \\
\hline Elutoni uxe & $88 \pm 4.1$ & - & $95.0 \pm 10.0$ & 66.8 & 73.5 & 99.5 \\
\hline 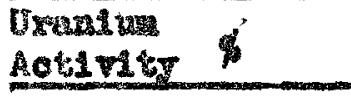 & $2.9 \pm 0.8$ & - & $5.5 \pm 0.2$ & 2.08 & 5.0 & 0.5 \\
\hline
\end{tabular}

Messurod activty bofore analysis $100 \%$ for the bete and alpha ocmpononts separately

2. 0 and the 2 


\begin{tabular}{|c|c|c|c|c|c|c|c|}
\hline $\operatorname{map}_{110}$ & $\therefore$ & & \multicolumn{2}{|c|}{ 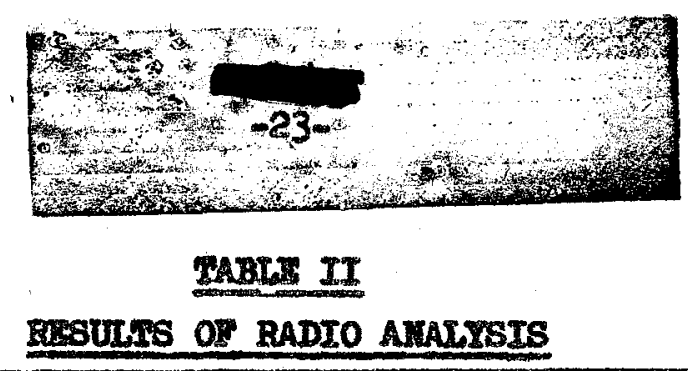 } & & $\cdots^{\prime}, \because ;$ & 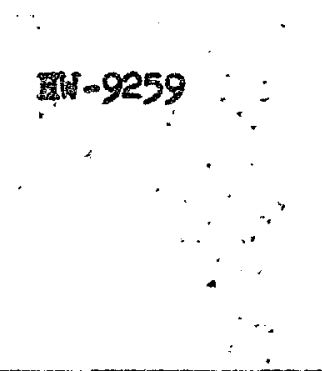 \\
\hline Particle & $\begin{array}{l}\text { Serapinge Froke } \\
\text { Fan Duet Worti } \\
200 \text { Iast }\end{array}$ & $\begin{array}{l}\text { Tiltox From } \\
\text { Strack Gases }\end{array}$ & $\begin{array}{c}\text { Filteres Irean } \\
\text { Dimolver }\end{array}$ & $\begin{array}{c}\text { Filters From } \\
\text { Tumnel Case } \\
200 \text { East }\end{array}$ & $\begin{array}{l}\text { Dumt From } \\
13 \text { \& Cell } \\
200 \text { Wost }\end{array}$ & $\begin{array}{l}\text { Hand RaiI Drop } \\
\text { From 200 Isst }\end{array}$ & $\begin{array}{l}\text { Fand Rais Drop } \\
\text { Prom } 200 \text {. Wint }\end{array}$ \\
\hline Iodine & $\ldots$ & 8.9 & $7.0 \pm 3$ & $\ldots$ & $2.93 \pm 1.5$ & 7.9 & 6.94 \\
\hline Corius & $21.9 \pm 1.5$ & 25.6 & $24.6 \pm 1.0$ & 8.2 & $3.0 \pm 2.5$ & 30.3 & 3.10 \\
\hline 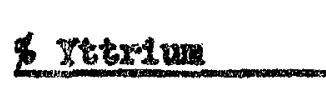 & $8.1 \pm 0.1$ & 23.9 & $\ldots$ & 21.7 & $2.1 \pm 0.5$ & 10.2 & 12.9 \\
\hline Dare Earthe ${ }^{2}$ & $1.7 \pm 1.1$ & .01 & $5.3 \pm 1.1$ & 0.71 & $0.8 \pm 0.7$ & 1.5 & 3.2 \\
\hline Sstrontiven & $3.9 \pm 1.5$ & 23.5 & $13.6 \pm 1.5$ & 3.65 & $3.75 \pm 7.2$ & 4.5 & -770 \\
\hline ERethons une & 8.32 & $\ldots$ & $4.3 \pm 1.5$ & 40.6 & $86.0 \pm 14$ & - & 0.0 \\
\hline Cosiun & $\cdots$ & - & $0.3 \pm .15$ & - & $0.1 \pm .2$ & - & - \\
\hline Elreonive & - & $=$ & $8.4 \pm 0.9$ & - & - & $\ldots$ & - \\
\hline Colurabiun & $\ldots$ & - & $1.4 \pm 0.1$ & $\ldots$ & - & $\ldots$ & - \\
\hline Esexzua & $=$ & - & $1.3 \pm 0.2$ & - & - & - & $-\infty$ \\
\hline Dolinesure & $\ldots$ & - & - & - & $=$ & - & - \\
\hline Anha Aot1 vitz & & & & & & & \\
\hline Bgutonatum & $\cdots$ & - & $21.6 \pm 10$ & $=$ & - & - & $=$ \\
\hline $\begin{array}{l}\text { Urantus } \\
\text { Aotsutity }\end{array}$ & - & $=$ & $1.5=0.8$ & - & - & $\cdots$ & $=$ \\
\hline
\end{tabular}




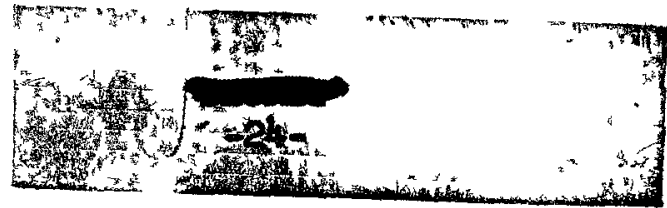

c. Io moesurable salubility of particle contmination in dietilled wator ves obeerved. This is gutto auxprising as one assumos throughont that tho particle is ofther a cerrior Por the rosidue from oveporated mist, or residue with no carrior. Pexhaps the arlginal met is coldic, and this property 18 loet by evaporation. The activity is removed by nitric acid.

a. Somo epot contamination opeolfically not aseoolated with carrier pertielos howed flesion product percentages peculierly difforent frcu those in the perticlos, with a very high strontin component in one cage. Whis could have been a "young" droplot. Uniortunately, the $8 x^{90} / \mathrm{sx}^{89}$ ratio wes not dotorminod.

- Activo particles have boen separatod fron natural rain, but nowe was active onough for redio-chowical analjols. The dlesolved activity in other rain samplos has been found more or 1048 aimiler to the particle activities, by effective helf-lifo. A hifher $8 \times 89$ content is not exclnded. Such actidity, known before the particle problen arose, has alvage been asermod to com from enitted droplets taken up by the rein.

8. Clinical teets - appled and proposed

Contrary to the vriter's flret extimate, It is now falrly certain that no vialbio raction vill rooult from prolanged exposure of the alin to a particle. Wo particle stronger than $0.3 \mathrm{pe}$ has been doterted in the pest two monthe, and the average activi by has boen about 0.004 pe. The Ingertion of elthor ane hot particle or 70 mall particles would not loed to a doponttion of $0.01 \mathrm{pe}$. Thero would bo no damese and cortetnly no clinicel symotoms from thes. Inhalation of such particles vould also probebly not lead to absorption and doposition in bods organe of mowe then this anount, elther diroctly from the Iung or by the cecondary ingoution of perticles ejected frem lung structurse. The remaining povelbility is of chronte irritation by 12redietion of lung tisere by a retainod particlo or particles. Io particle can destroy wove than a sphore of a for ull11motors radius in tienuo. The expectation of clinicel alene might concelvably be doduced fron ortdonse fron chemical varfaxe non-radicactive irritents. It is provistonalis dednoed thet it is valueless to malse direct olinical obeervetione an potantialis exposed poople.

Tho external radiation from a Iung-depoutted perticlo is below the feasible IInit of detection, nor is the use of eleborate dotectsion inetruments for insertion in the bronchus vot bihile. (The external radiation can be messured in anall laboratong animalo).

Close inspection of the clothing and body of persomel has its place in the eetimation of the lilbithood of exposure. Several hunixed mon have been so examinod, with the positive resmits confinod to shoo contamination.

Inepection of reeps rators worn in conteminated sonos is mose indicative of the Inhaiation hazard. Iwelve thousand respirators heve been tested by Colger Countor mothods. Two contaminated masks wore reported. Ono of these bad 4 perticies on the imer face of the Plltor pad, and there is conaldarable donbt as to wethor thoes axrived thore by breathing.

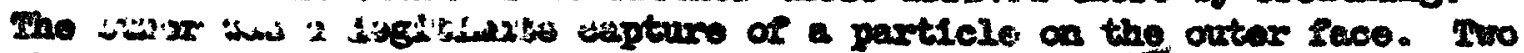

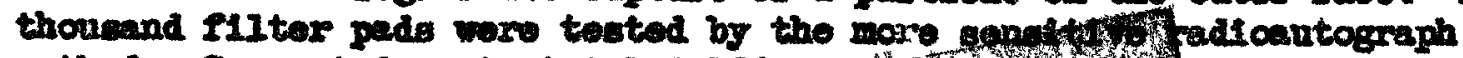

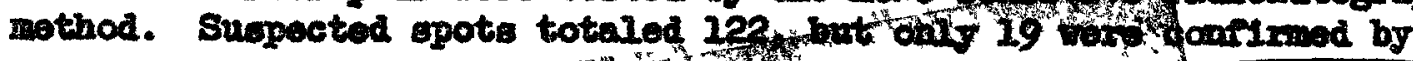

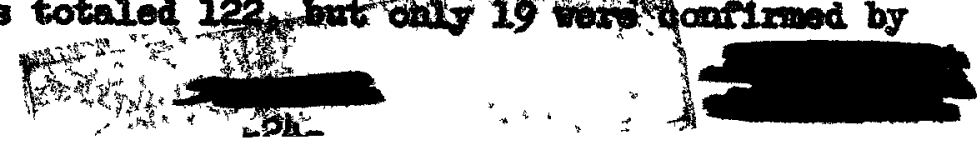

$$
\begin{aligned}
& \text { :..... } \\
& \text { :... : } \\
& \text {....... } \\
& \text { :..... } \\
& \text {....... } \\
& \because \cdots \\
& \because \bullet \\
& \therefore \\
& \because \ldots \\
& \text {...... } \\
& \therefore . . . \\
& \text { ¿.... } \\
& \text { :.... }
\end{aligned}
$$




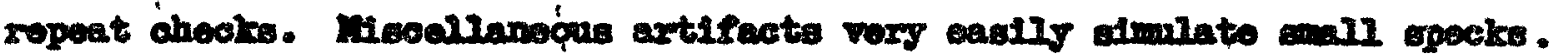

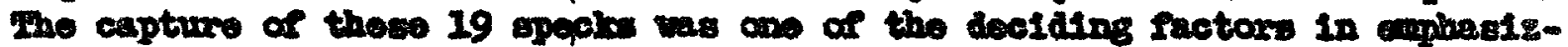

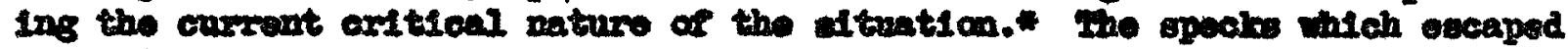
dotection by countere, but regiatored on PIIn probably had activity not in

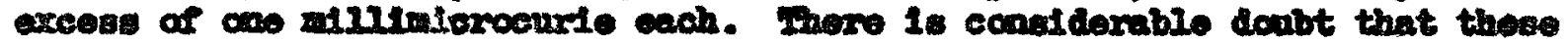
voro hasarious. Calibration of the film ayeten has not yot been derinod.

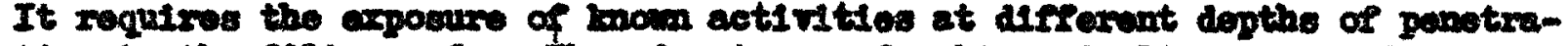
t1on in the filter pads. Tho advanteges of maling elmintanocur radio-

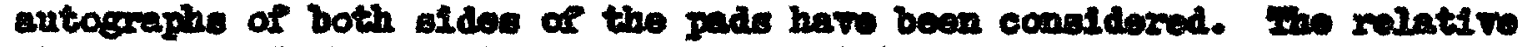
blackening of the two III spots in regdoter would dotandins the position in dopth of the cotive perticle and thus improve calibention. Alwo, un-

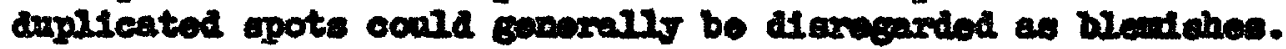

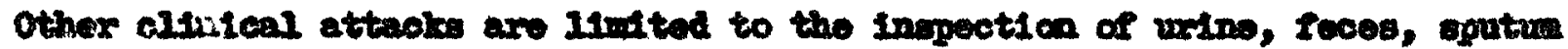

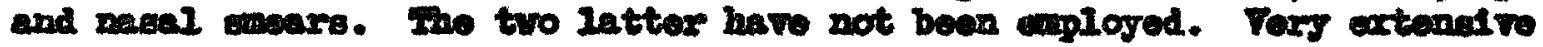
prograne would bo noedod to eot alenifleant date. Thoy will be used if a person if thout rosplrator inadvertentis outers a zono of high particle concentration.

Boutine urive anplos have show no lang lived ectivity, nor is ang to be

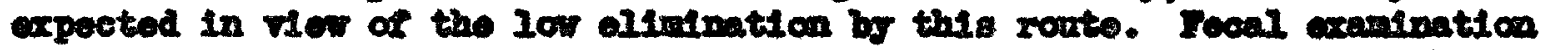

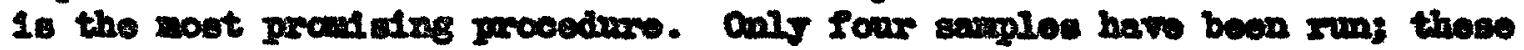
wore all frov from radicactive coutanination. Jolnt oondidoration by the Hodical and F. I. Dopartante is boing given to the precticability of large seale analjals of feces. The primary objecti wo vould be to dotect the elimination of partioles dopostted in the Ims and then sullowod.

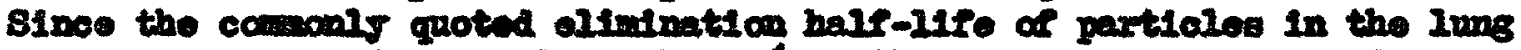

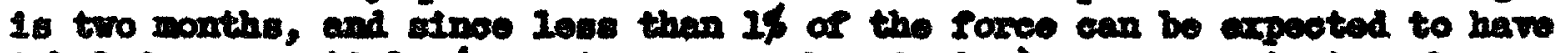

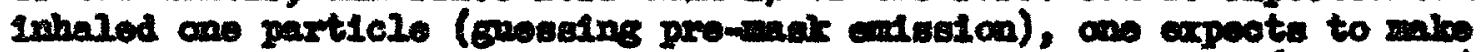

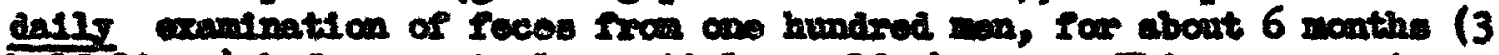

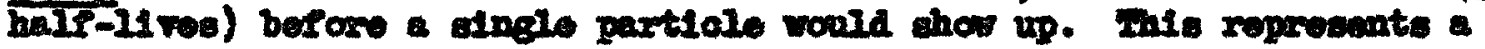
tromendous and mattractive progrm. Sveh an offort would be roquired in the event of breakdom of noxte af the Poree. Although this morreis is

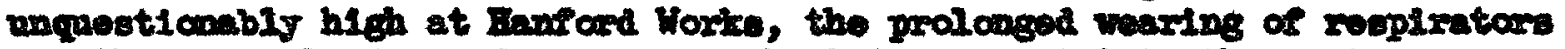
and the removal of mon frow cortain bulldings conotituto the most movere

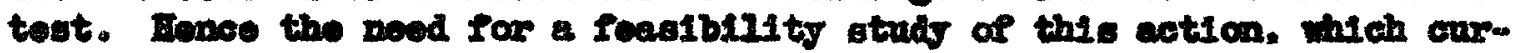
rontis appears to be the colly proulefing approach.tis

Aceoes to extoper matorial of axpeed perecernel would be inutruotive;

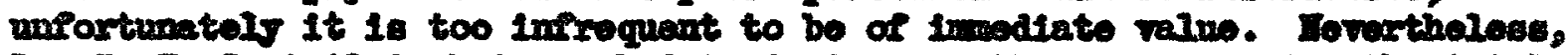
Dr. S. I. Cantarl is boling adked to dorine a mothod of proparing the total

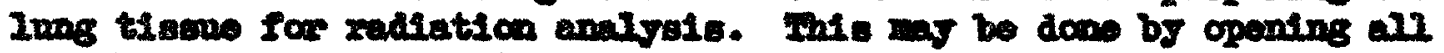

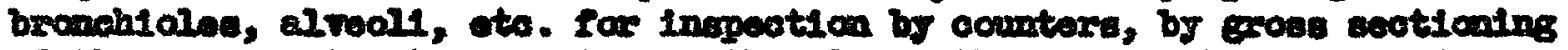
of the organ into alice not mowe than 1 m. thick, by ashing or by digertion or bottor moan jot to bo studied. It all ovente, tho procedine vill be difriente. The 21 ver will be anothor crgan of intarost. Tho arecution of ucos woh plan is expected to be essentilal for the longrange allaying of legt timate exployee or publie fears.

- For estimated uoe-frotor of 0.8 hour por anak, this show that a man vould have ishaied ons particie por 2.5 voors, in good agrecuint with the one per weok caloulaticns.

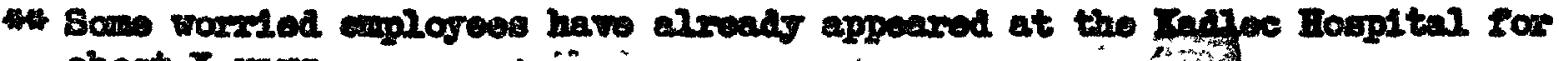
chest X-zurs.
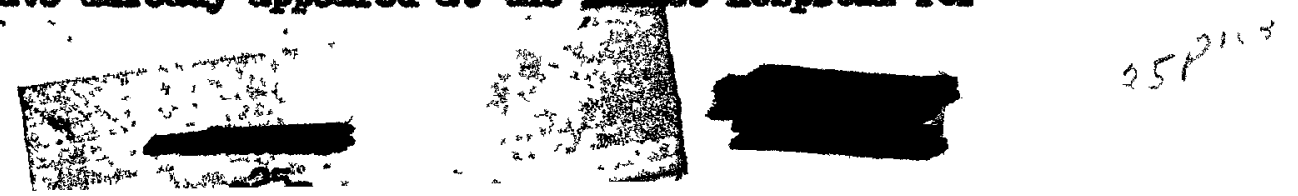


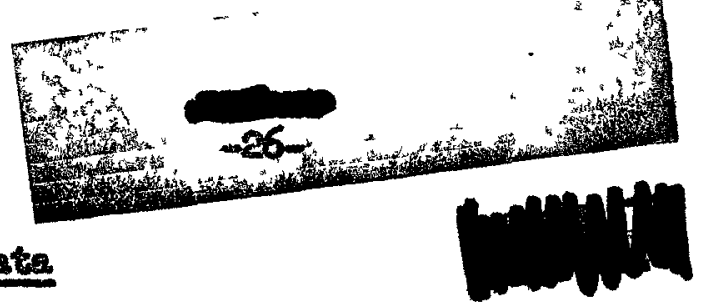

9. Inforepoee Excen past data

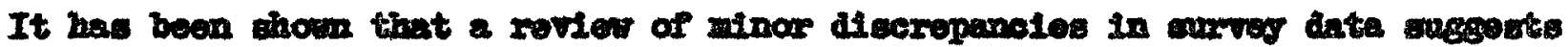

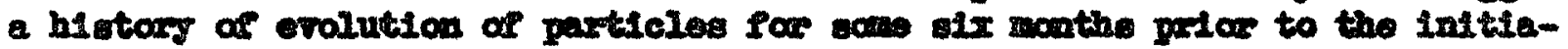
tion of protective maenrve. It is also known that mist or dropilet vero

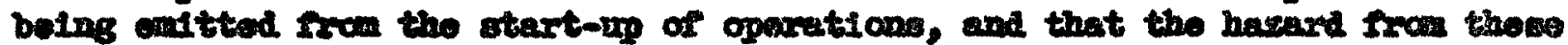

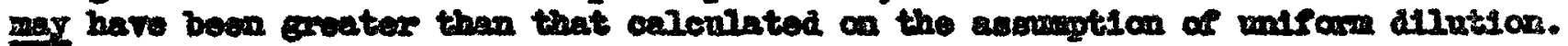

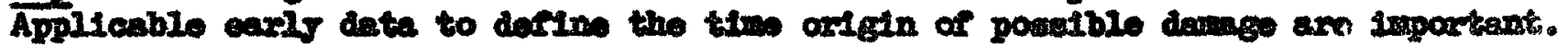
Dhe courees are four in mubers

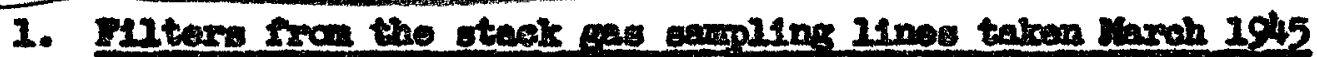

These vore the filtere that derined the onission of Mlesion producte and of

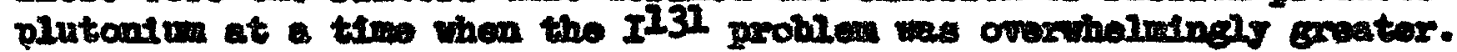

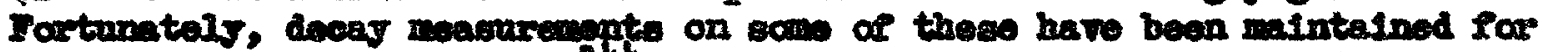

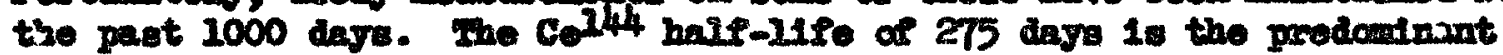
prosmed activity. Decelculation of otacli enisaton at the tine of the

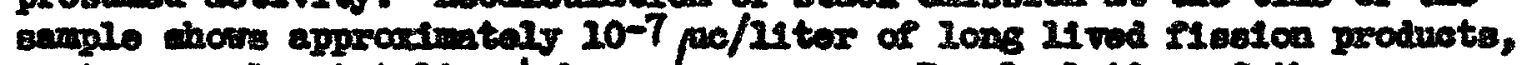
on two samples totaling 4 houres coverage. Beesteriation of the concurmint oudesion of IIS1 as ahown by thoes 11Iters indicated about $5 \times 10^{-3}$ pe I I31/2iter ataol gas. As the f1ltors woro started on courter teste col hundred daje arter exposure, this valne has been corrected by a

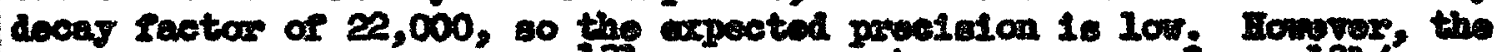

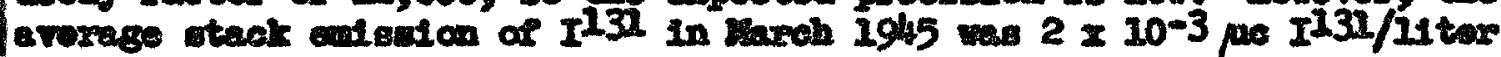

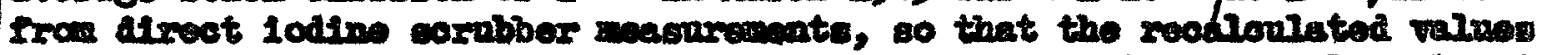

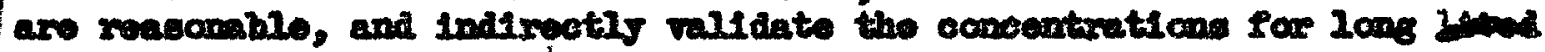
actirities.

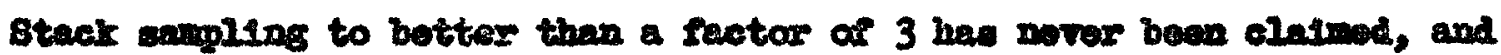
J. B Hork beliewes that Inotuaticen by a factor of 10 aro poesiblo. It vill bo eeen Iater that we are practicalif foroed to tho conoluolon that the above value is $10 \%$.

An ieportant observation is that no digexete particle can be found on these Plitors.

\section{Simina filtor tairen Jebruar to Jur 1947}

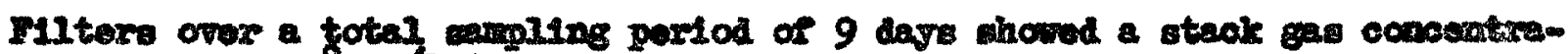

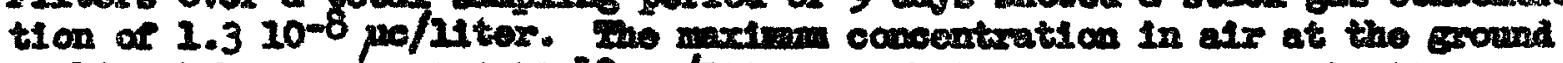
could not have exceoded 10-10 po/I1ter, with the averege concentration no noxe than 10-11 $\mathrm{po} / \mathrm{Ltex}$. Jpon re-sxemination, one of the vangles run for

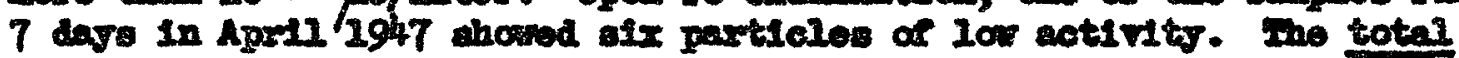
activity of the eample, including distributed setivity was oni $\frac{1}{8}$ I $10-3$ po. It follow thet the corrosice debria problen had not otarted, ar was juet starting at this dete. Host probeble is that those particles aro cust Which callocted a lith ectivity in trensit through the roten.

\section{Air genple in Biahland, Maroh 1945}

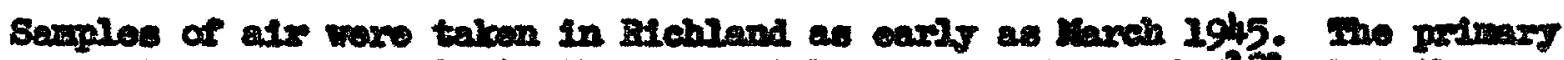
objective to evaluate the then Ieh conoentretica of Ilis, but the

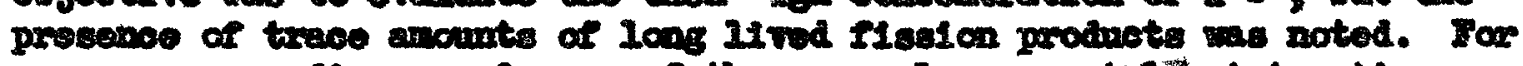

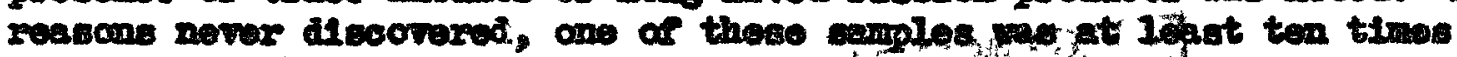

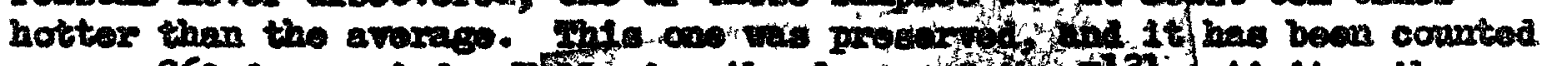

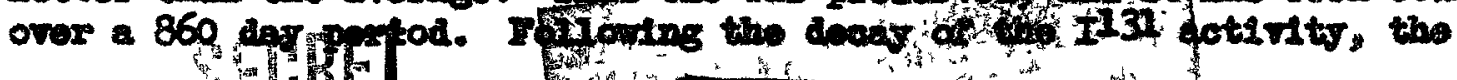




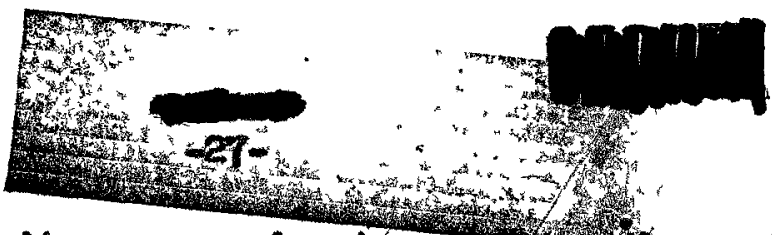

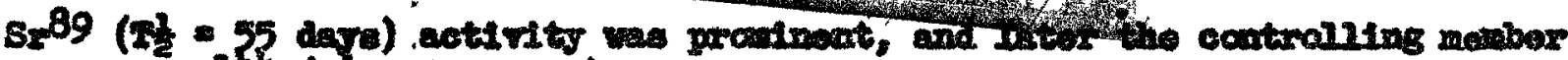

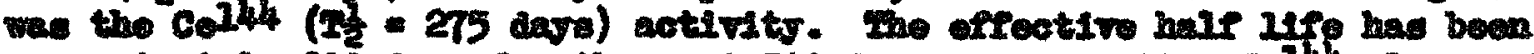

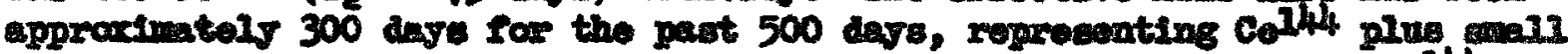

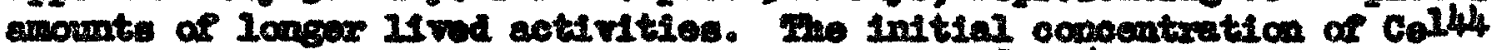
plus longor lived aptifities in air was $2 \times 10-9$ no/Liter, overa elve day

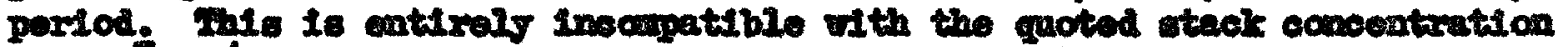

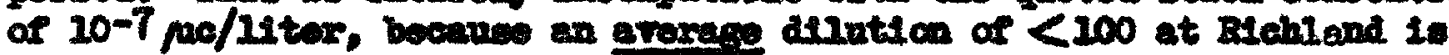

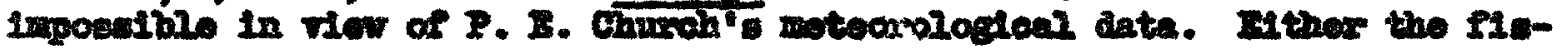

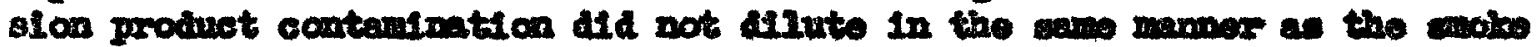

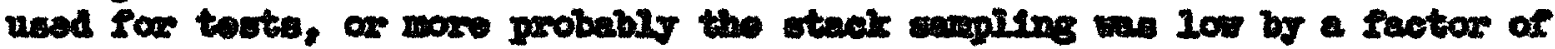

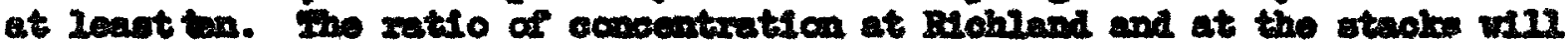
have to be more thencughly investigated to chosk

(1) Acouracy of actipling.

(2) Poselbility of etcaly acoumintice of aotivity in wagnant air condstitons.

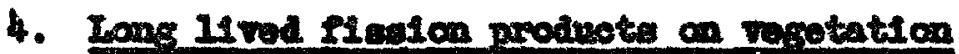

In the early dars of oporation, with short cooring time frotifled by the war

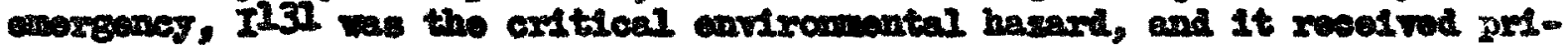
maxy attention. Fevertholess, trace anounts of longer 11vad cotivitios were doteotad on desart regotation at an carly date. After on rear of operstica, this ancunted to approudmately $0.05 \%$ of the total aotivity, and this rowe to 10 after about 2 years. In the moantims, the Il31 had boen reduced by a factor of about 10 , by additional cooling time, so that the Iong Ifved activity approcimataly dosbled. Thore has been ilttio furthor inereace in this activity, although it is now conparable alth the II3I oct17t the to a furthor increase in cooling tim oquivilent to II3L

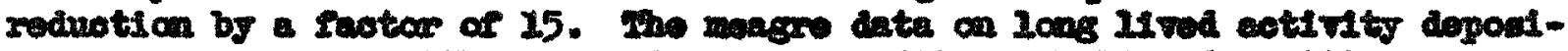

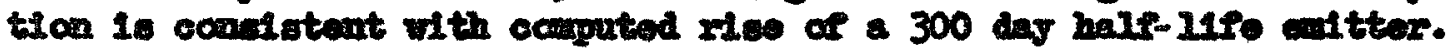

\begin{tabular}{cr} 
Oparation Pine (vears) & Rolative total set \\
\hline 1 & 100 \\
2 & 145 \\
3 & 162 \\
4 & 170
\end{tabular}

It 28 anound that proinction rate and prosese operaticn heve raminod

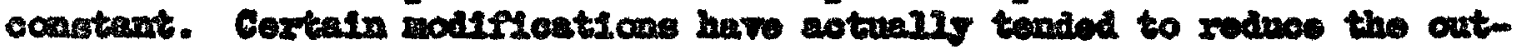
put of conteminated dropletes as is cubstantiated by the rouped coneontra-

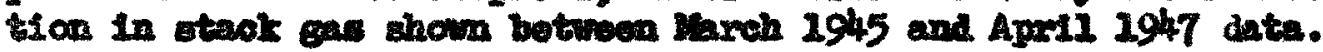

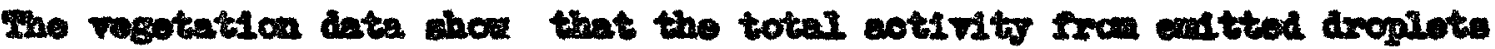

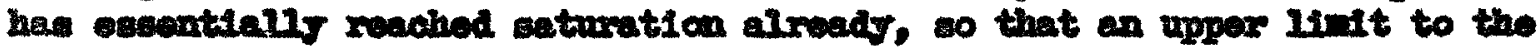

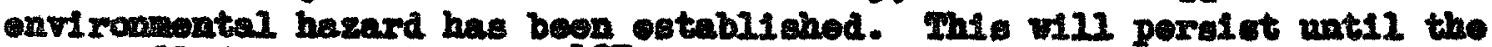
meak 8 r90 (25 Joare) and Ca137 (30 years) aserume control of the affective half Ife. It will be inexcuseble if the anesion of ench activities is not alininated shortly.

If the environe of the plant were conteninated of th i pattern of alscrete particles of long lived activity, the analyois of many one-gran samplos of vegotation would shor wide rariations. With the $11 \mathrm{mited}$ meterial at wgh, this in not the cane.

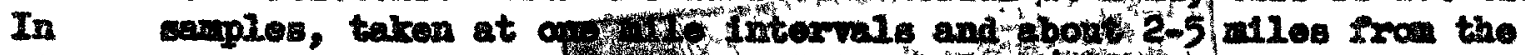

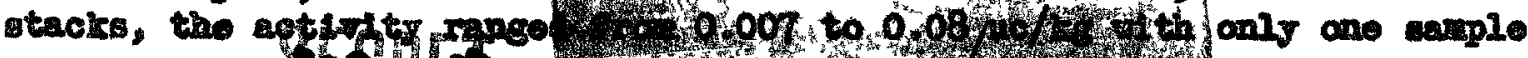




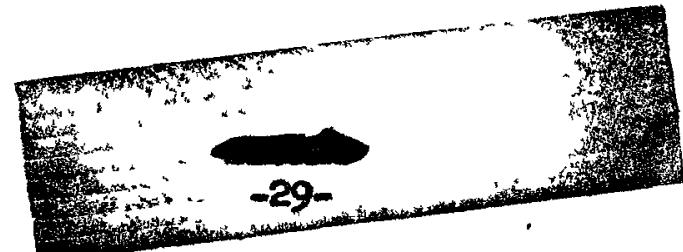

noeded es to whothor $1 t$ is foarbio for a particlo to otay in the lang lans encugh to do damage and then be ranoved before the case pxocesis to antopay.

If Ingalment of houlth 18 claimed, there appoure to bo a poor chance of obtalnIng dorinitive eridence. Pezhaps ouly prolonged analyais of feces is apo pllcable. Clatne not apported by olinfeal symptong of lung damege might be

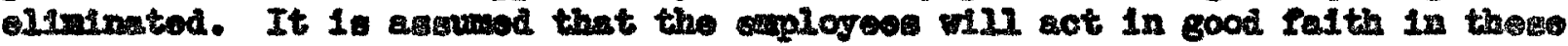

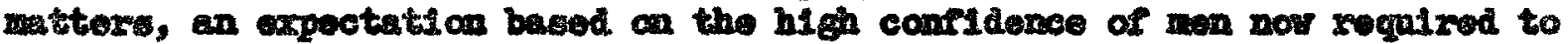
vork in potontially bagrarious areas. More unreabcable clains are to be

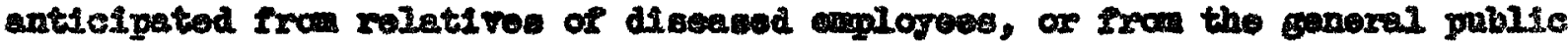

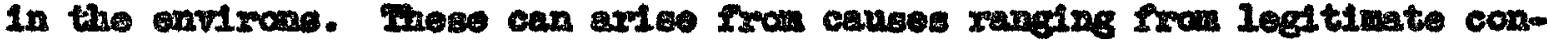
cern over problens overemphasized in the prose to outilght fraud. Tho thooretical posalbility of injury developing 10 to 15 roars frem nor poses a serlous problea.

It Is imperetive that the best poselbie talerane experiments should be sonducted on particulate contanination expoeure. Hhothor these should bo dono In wole or in pert at Inaford should bo decided by cutelds consurtante.

\section{Congul tative Aseistange}

The following porson or organdzetions have been approached or will be apgrosched for additionel guldavoe:

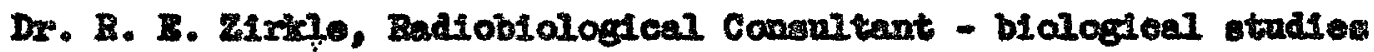

Ix. S. T. Cantril, Hadical Correnitant - clinical offeets

Dr. P. X. Inad, Pathology Conenztant - (In procesa) - tisene darage

Dx. I. Iangmir and T.J. Seheorex, - Ilms particle otudiee

Dr. Shilals Varren - radiation dameo

Dr. G. Fallia - hoalth phytics

Dr. P. F. Cunreh - Moteorologs Consultant - treneport of partlelos

Hoather Bureau - tranoport of partieles

Cherateal Warfare Serrice - particles in Iung

Dr. F. Notiean - Aleporal of partleles

Sellex Corporation - stack decontaninatica

Air Reduction Company - otack decontarelnation

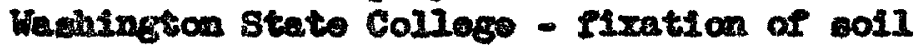

Buders of this doctuent are Invitod to advise us of other appropriate referenco sources.

\section{Swerry of Swomites}

Guantities of the arder of ton ailiton to 100 million malcactive particlos por

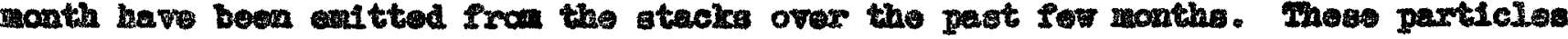
hew an offective zadicactive half-11Pe of about 300 dajs, wh th trace anounte of

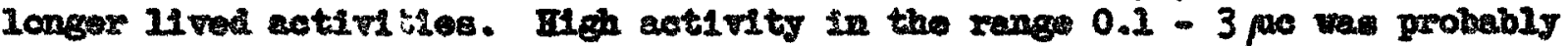
confined to large currier partieles of corrovion debris from Iron anotwori in the

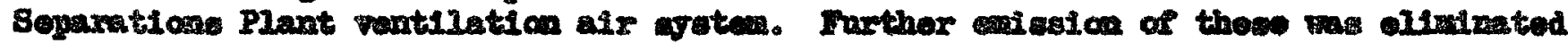
by replacement of the duetrorts.

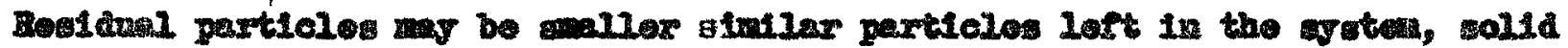

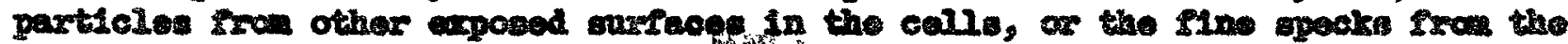

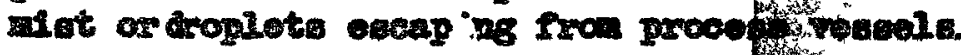
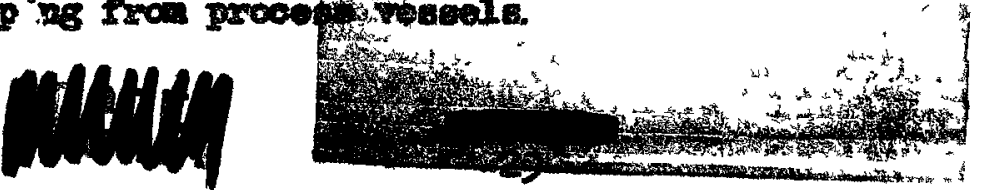

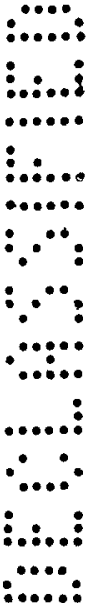




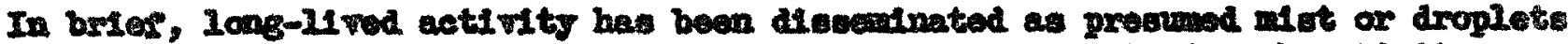

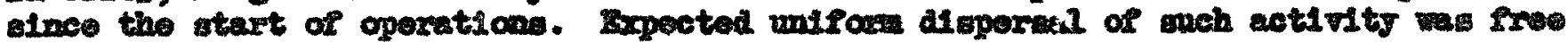

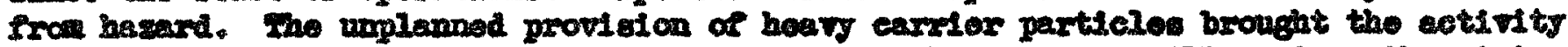
to ground wach eloser to the stacks. Rewovel of the carriers ofll restore the status quo. In the $100 \mathrm{~g}$ range vies this wide dispereal of activity should be elineinated to

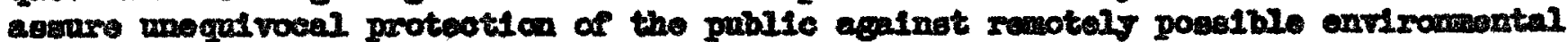
baserd. Possible radietion darage from these particles io poordy underrtood.

81gniflcant dawase probebly onl fallours inbulatian. Particles of progreselvely

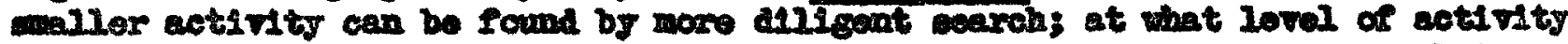

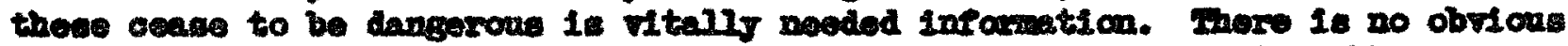
mothod of detocting particles in tho Inng. Sextous medieo-iegal pxobleme aro theroby introduced.

Corrective stop have been epplled to runove Iarge particles fran the stack aix, and

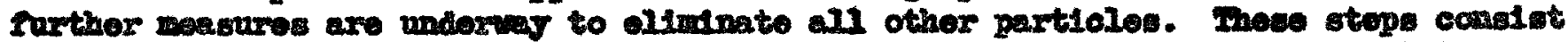

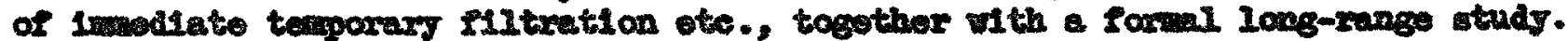
Pereomel protection has been afforded by respiratore.

A restave of a few million partieles on the grownd in the onvirong of the Separation plants vill requiro elther renovil or fixation to provent imhalation baserd by ro-entry of particles into the atmospherv. Meane of exfecting this appoers costly and hould be hold to the Ininima ares conelistent with wafoty. It follow that the trenoport of particles and posalble pature coneentration in areas currently weekly contaminated has to be known.

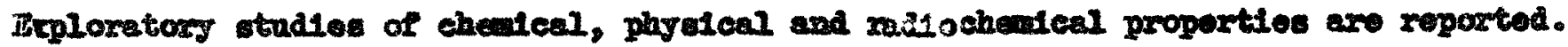

Scase approsehos to calculations of perpilagible exposure are firon in the appendix.

Tunetion and nature of this report

The report was accumalstod frce date doveloped by severel dopertapate, and wany wubdivislans of those departinents. Although tho mela assignnonts have bean indicated no atterpt has been ade to crodit, in dotall, the alenonts of this fine cxample of intordepartmontal callabosation.

Aleo, in vies of the wrgency to present a broad pieture of the problem to intereeted parties, time has not boen epont to ealt the roport. DIrfusenesp, ropotiticn and posalbie 11 logical ordor of topice should be accepted in the intervet or oped. This is not a Iinal roport. In faot, it is clowod tis a paregreph on mindinge doreloped alnce the roport val atartod.

\section{Late Reouits (to $3 / 26 / 48)$}

1. Texposery filter were installed in the 1 plent Canjon Building collo on 3/22/48. Subeogrent Technicel Dopartzant semplea $\mathrm{man}$ as Iallowa:

\section{Activity}

Duration Mos on PIIter

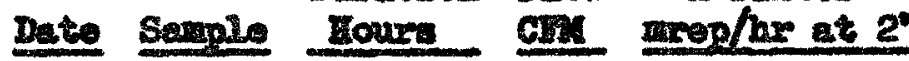

$3 / 22$
48 $\left[\begin{array}{ccc}1-12 & 4 & 10 \\ 72-14 & 4 & 10 \\ 14-16 & 4 & 109\end{array}\right]$

10
25
25
Rowarica Ialbio Particlea Dotoctabie Particlos

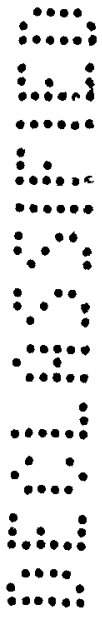




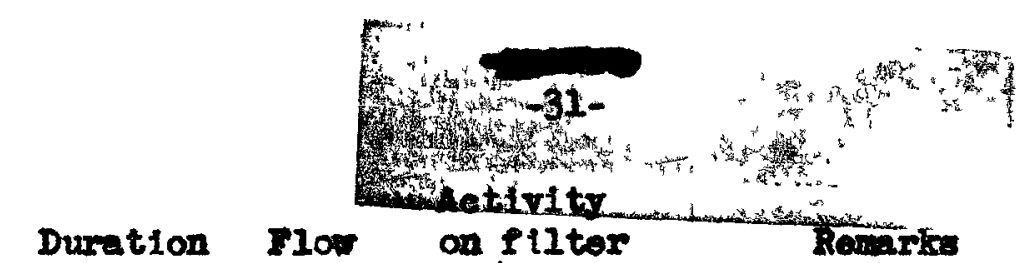

\begin{tabular}{|c|c|c|c|c|c|c|}
\hline Date & Sample & $\begin{array}{l}\text { Duration } \\
\text { Houre }\end{array}$ & $\begin{array}{l}\text { P10\% } \\
\text { CEx }\end{array}$ & $\begin{array}{l}\text { on filter } \\
\text { mep/hr at } 2 "\end{array}$ & $\begin{array}{c}\text { Romarke } \\
\text { Vislblo Particleo }\end{array}$ & $\begin{array}{c}\text { B. I. } \\
\text { Detectable Particles }\end{array}$ \\
\hline \multirow{3}{*}{$3 / 23$} & F1-13 & 18 & 10 & 500 & 0 & $905, D, 9 R$ \\
\hline & I2-15 & 18 & 10 & 500 & $30-50$ & 15. 1695 DD $10 R$ \\
\hline & $\$ 4-17$ & 18 & 10 & 500 & 0 & $758, D, 17 R$ \\
\hline \multirow{3}{*}{$\begin{array}{l}3 / 24 \\
48\end{array}$} & $81-14$ & 24 & 10 & 500 & 24 & $20 \mathrm{~L}, 100 \mathrm{~S}, \mathrm{DD}$ \\
\hline & $72-16$ & 24 & 10 & 400 & 6 & 16t, $350 \mathrm{~S}, \mathrm{DD}$ \\
\hline & F4-18 & 24 & 10 & 1100 & 0 & II, 395 \\
\hline \multirow{3}{*}{$3 / 25$} & $1-15$ & 24 & 10 & 30 & 12 & Bos, D \\
\hline & $22-17$ & 24 & 10 & 30 & 24 & $10 \mathrm{~L}, 200 \mathrm{~s}, \mathrm{DD}$ \\
\hline & F4-19 & 24 & 10 & 750 & 0 & $11,255, \mathbf{D}$ \\
\hline \multirow{3}{*}{$3 / 26$} & H-16 & 24 & 10 & 900 & 2], 18 & 4L, 75S, DD \\
\hline & $72-18$ & 24 & 10 & 750 & Many $S$ & 715 \\
\hline & $54-20$ & 24 & 10 & 1650 & 0 & 145 \\
\hline
\end{tabular}

\section{$I$ - larpe particle $(>0.5 \mathrm{~min}) \mathrm{s}=\operatorname{mall}$ particlo \\ D = Dust - DD- = much dust - R - perticlo detected by sadiograph}

The particles were obtained by tappinf the 1 ltere, the residual being moasured by radicautography.

There has beon a fonoral roduction of activity from about $5000 \mathrm{mrop} / \mathrm{hr}$ per day to approx mately $500 \mathrm{mmep} / \mathrm{hr}$. Clearly, horerer, the problex has not been conteined by the addit; an of these Plltere. Prosumably thore is a logacy of particles in the ventilation system, that will tond to be emitted eporadically.

2. Tho IIIters of March 1945 have been radloautographod agein over a lone period. One minor spot vas found. Whethor this wes a minute speck of dust or an oarly correglin particlo is unknown. That. is is nnt a dri ed dronlet nneck

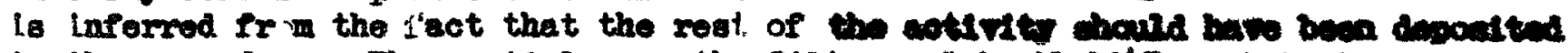
in the same form. The particlos on the fllters of Apri1 1947 contain iron and prosumbly cams from tho ductrork.

3. The curveyed area in the 200 East hrea has been radlcally axtended to cover a rectangular aection $7000^{\circ}$ by $5000^{\prime}$, somprisine the $\mathbf{S . S .}$. quadrant of this Area, and conteinine the B PIent steck at Ite B.W. corner. The surfece concentra-

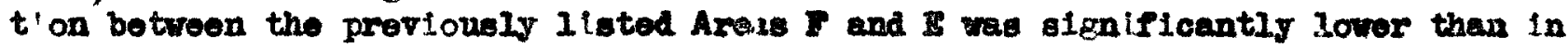
$\theta$ ther one of these. Beat of Area 8 , the concentretion foll very repidy to 0.06 par. It to now euspect ed that paxticlea hare drifted fag relatively

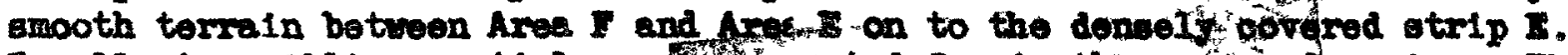

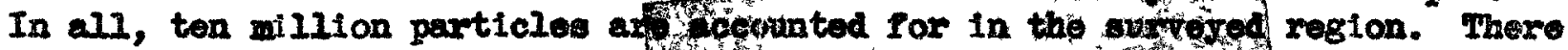
Is reason to feel now that most by the problem will be ofothly in the area, 
ospecially as particle act'vity appears to vary more or lebs inversely as the diatence from the stack.

Averece Activity of particles es a Functlon of Distance from the B Plant Stack

\begin{tabular}{c}
$\begin{array}{c}\text { Dietance (d) } \\
\text { feot }\end{array}$ \\
\hline 1500 \\
2000 \\
3000 \\
6000
\end{tabular}
Activity A

mic

9

7

4

2
Axd. mix - feet

13,500

14,000

12,000

12,000

Appendix

Calculations of parmiasible exposure

It is not claimed that one can calculate the active particlo hazard realistlcally. Stendard mothods are adapted here to give order of magnitude of the hazard.

Fission product mixture, effective energy and sphere of action

Take a simplefed pleture in which one microcurle contains

$$
0.3 \text { pe Col44, } 0.3 \text { pe Prl44, } 0.2 \text { pe sx90, } 0.2 \text { pe } 90
$$

This ulll make the radiation hazard worse then it is belleved to be. The enercetic beta radiations are PrI44 3.07 $\mathrm{KoV}$ and $9902.16 \mathrm{MeV}$ - Take an everaze of $2.6 \mathrm{Mol}$ as Bwax

The enerfy from a simple particle will ossentially be diseipated in a ophere of radilus de definod by $d=$ range for $\frac{\text { Emax }}{2}$

$\mathrm{d}=$ ranco in $\mathrm{t}$ sene for $1.3 \mathrm{Hov}$ = epproximately $0.5=\mathrm{cm}$

Nase of ephere $=\frac{4}{3} \pi(0.5)^{3} \mathrm{gm}=$ epproximately $0.5 \mathrm{gm}$

Cambe radiation may be nexlected, and the effective energy of the beta radition is

$$
B=\frac{1}{3}[0.3(0.35+3.07) 0.2(0.65+2.16)] \mathrm{MoV}=0.53 \mathrm{NoV}
$$

The wost pesoiniatic ophere of action has a radius = range of 0.53 Mor bete. radiation $\mathrm{n}$ tisaus $=0.18 \mathrm{~cm}$

$$
\text { Most pestinistic mase }=0.024 \mathrm{gm}
$$

Case 1. A atnelo particlo of activity $2 \mu$ remaing in one position in the lune.

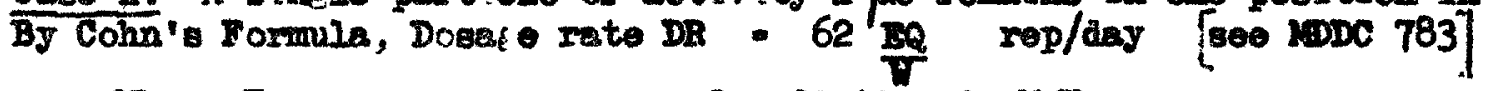

There $\mathrm{I}$ - arerage enorey of radiation in $\mathrm{HeV}$

$Q=$ ue deposited

$W=$ Ereme of $t$ soue in the sphere of action.

D.R $=\frac{62 \pm 0.53 \pm 2 \text { rep per }}{0.5}$

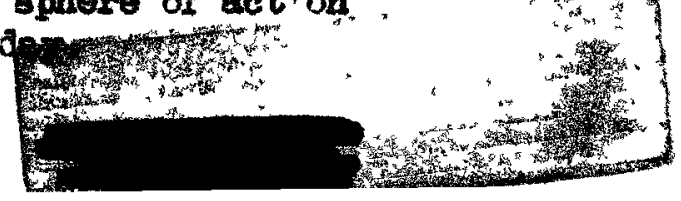
$32 p^{103}$ 


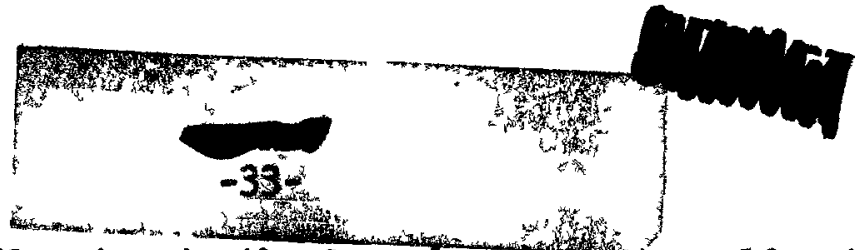

Eiv -9259

Such a particle could hardily gtay in the lune (oven ils it could got thers in the Pirst place) Por wore then one wonth.

The total dose would be about 4000 rep. A couparable dose in a comparable ephere of action lo elven by the gama radiation from a one millcurie gold seed.

For the most pessinietio ephere of action,

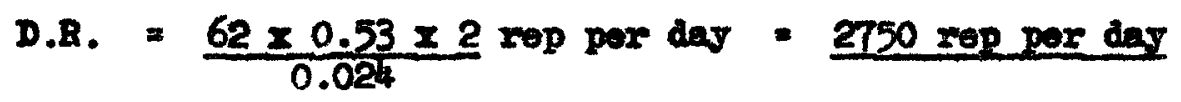

It was on some such besis that the witer prodicted a sisin reaction from contect wh the particles. The absence of such a reaction tende to oupport the calaulation for the larger ephere of action.

Case 2. Activity of a particle that is unoquivucally safo

Such a perticle will five 0.1 rep per day or 1080 in the sphere of action.

$$
\text { Permissible activity }=\frac{2000}{1300} \text { mpe }=1.5 \text { mpe }
$$

Or for the most pessimistic ephers of sction,

$$
\text { Permiasible sctivity }=\frac{2000}{27500} \text { muc }=0.07 \text { mpo }
$$

Cage 3. Inlform lung deposition from an aerosol

It is customary $t$ assuns that $25 \%$ of the avelisble particles are initially reteinod in the lune, and that the blological elimination rate has a balf-ilfo time of 2 monthe

The redietion halfife to effectively 300 days

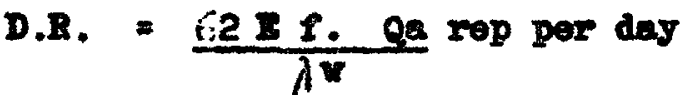

$$
\begin{aligned}
& \text { whore Qa - total activity (po) broathed in per day } \\
& I \text { - fraction retainod }=0.25 \\
& \lambda=\lambda \text { radiation }+\lambda \text { blological }=(0.0023+0.0115) \\
& =0.014 \text { day-1 } \\
& v=\operatorname{total} \text { maes of Iunge }=1000 \mathrm{em} \text {. } \\
& \text { For D.R. = } 0.1 \text { rep per day, } \\
& \text { Qa }=0.1 \times 0.014 \times 1000 \mu \mathrm{c} \text { por day } \\
& 62 \times 0.53 \times 0.25 \\
& \text { - } 0.17 \text { pre per day }
\end{aligned}
$$

Plant anployees breath 1 cuble moter of alrpor hour for ton houre daily exposure, In the sbsence of other exposure, permissibio concentration of the everosol is:

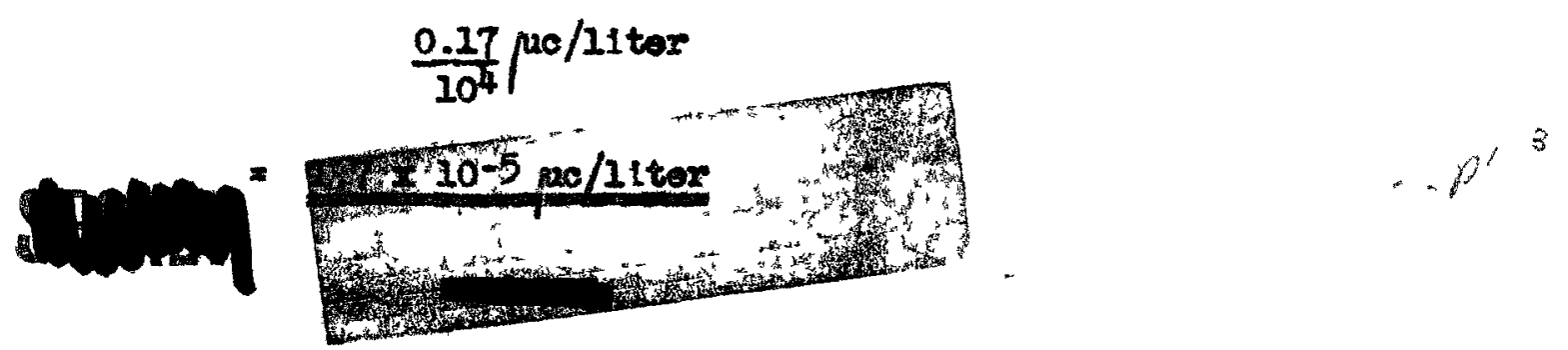


ER- 110

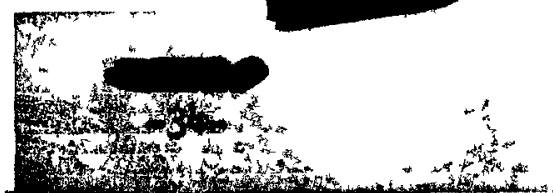

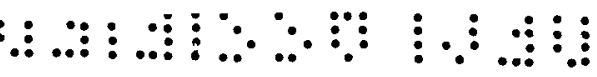

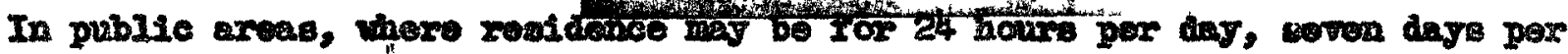
nook

$$
\begin{aligned}
& \text { Pexnderible aerowal concantratsion }-\frac{1.7 \times 10^{-5} \times 10 \times 5}{24 \times 7} \text { pe/1itor } \\
& \text { - } 2 \mathrm{pmel} / 21 \mathrm{ter}
\end{aligned}
$$

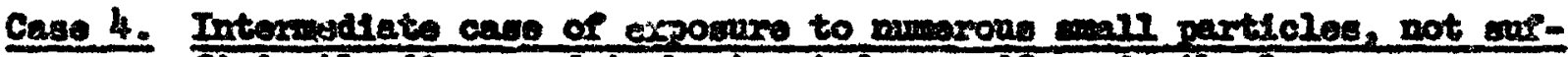
incientir dispereed to be treated as unifore in the Iung

This Is the caw of inmaliate Intereat, and naturaily is the one that can be culculated vith least cortainty.

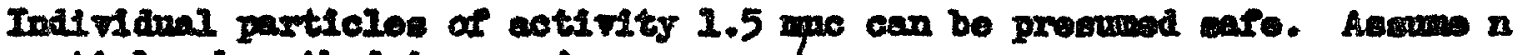
perticles broathed in per day

Total number in Iumg $=\frac{e_{0} n_{0}}{\lambda b 101}-\frac{0.25 n}{0.0115}=22 n$

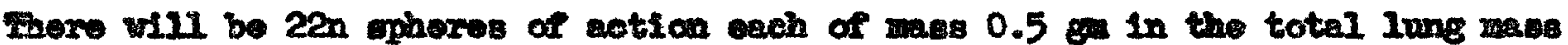

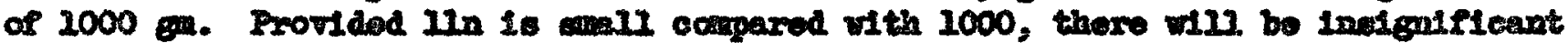
orerlap of the sphores of action.

n -5 givos 10 probability of orexiap

Thorefore, it 16 safe to inhale 5 partieles per day of activity 1.5 wpo or lows.

From this point, celcelations of the haserd of the reel field conditions bom cons inore and noro epeculater

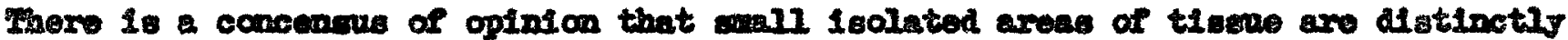
more radicrestetant then are 2 arge areas, pexheps dne to the ease with which the bod can warahall reparativo agonts to the 1rxadiated elto. Suppose this ropresente a fector of 5 between the whole body and a gphore of maes 0.5 Ga. Then 1t vould be eafo to inhale 5 particles per day of activity 7.5 ape or 1083. It is not abeurd to axppose that one partiele por das of actitity 10 upe conld be tolexated.

\section{Distribution of perticlea entted from the etacks}

This ment bo celculated or moagured by coupotent experts. Provialonally, the Idearired equation of Bosenquet and Pearson is applied to the cese.

$$
N_{0}=\frac{N_{t} \cdot 10^{-6}\left(1.78 H / k_{1}\right)^{V_{11} / k_{1} v_{x}}}{\sqrt{2 \pi} k_{0} k_{1} \cdot v_{x} x^{\left(2+V_{m} / k_{1} v_{x}\right)}} e^{-H_{k_{1} x}}
$$

where Ho - muber of particles pex cublc seter of air at grcund 2 grel

IIt - rumber of perticles entited par day * approxinatoly 106

I otack bolght - 60 notors

$I=0.08, k_{1}=0.05$

Vx - velocity of wind a 2 moterc/bec., wy

$x$ distance from atack in direction of wind

V. - torninal velocity of particies

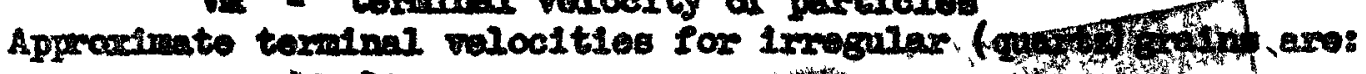
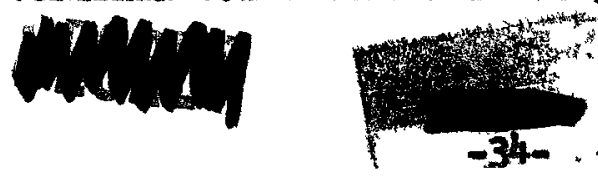


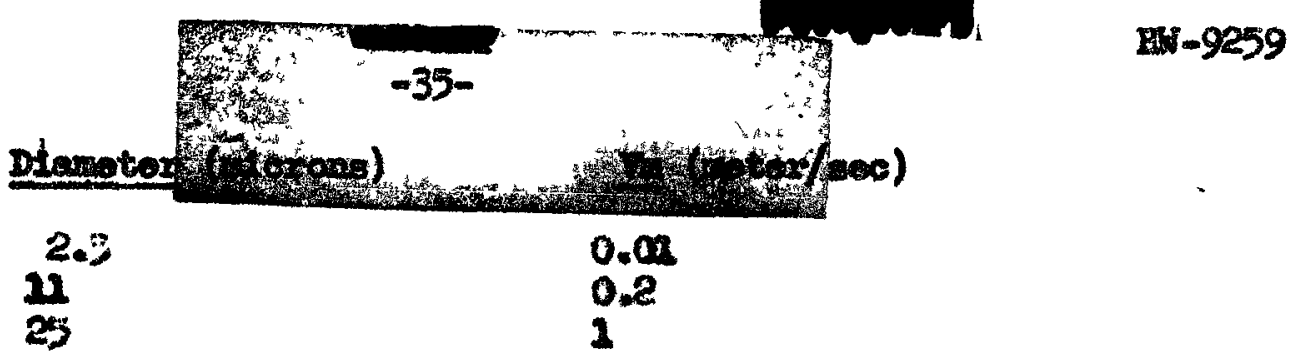

The following valuar arine from those essmptions:

Approndinato

Particle $61=$ Eterans

$<1$

2.5

11

25

$\sim 50$

$\sim 100$
Toratival

Voloeity

noter/see

0

0.01

0.2

2

2
Peet

Concentration

Perticled/c. moter

$2 \times 10-5$

$2.4 \times 10-5$

$5 \times 10^{-4}$

$(5 \times 105)$

largo

large
Diutance of Peak Irom stack Ieet

2200

2000

1000

320

160

80
Partieles Inhaled per weok:

$$
\text { 10-3 }
$$

$1.2 \times 10-3$

$2.5 \times 10-2$

3

too large to be inhaled too large to bo inbaled

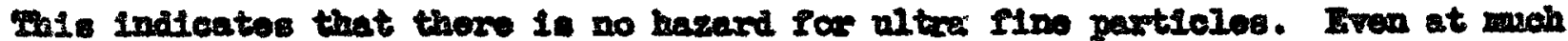
lower vind velocitios, the concentrention would not rise to hagandous lovels. Qualltetively, it is alvo cloar how the production of carrer partieles in the gystem brought acwn showers of partioles in high comentration and close to the steck, thu louking to doteotion. Particles in the main range ar intereat $(2-3 p)$ babeve easentialiy as particles with sero terninal velocities.

Wind trangpont of particles

This rant be solved by competent experts; in the interin, a crude order of ragattude calculation way have sone value.

Dalla Valle' Iormia modifles tomt

$$
N_{0}=\frac{k^{2}\left(c_{1}-c_{2}\right)\left(v_{2}-v_{1}\right)}{\ln ^{2}\left(z_{2} / x_{1}\right)}
$$

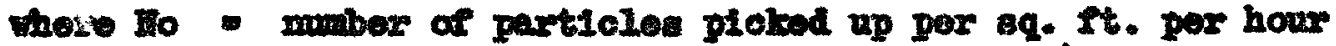

X Ton Earmen' turbuiance congtant - 0.4

$C_{1}, C_{2}$. mumber of particlos per cublc foot at two 10vels

$\mathbf{z}_{1}, \mathrm{z}_{2}$ (moters)

$\nabla_{1}, v_{2}$. wind veloelty $(\mathrm{ft} / \mathrm{hr})$ at those 10vele

For a severe dust etorn, typical date" axs:

$$
\begin{aligned}
& c_{1}=2 \times 109 \text { at } z_{1}=1 \\
& c_{2}=6 \times 20^{8} \text { at } z_{2}=10 \\
& v_{1}=20 \times 5280, v_{2}=17.4 \times 5280 \\
& \text { Honce, } v_{0}=5.8 \times 10^{31} \text { par per hour }
\end{aligned}
$$

Nore arbitrarily asmene that this gtore blows for 10 hours

$$
\text { Total pick up }=5.8 \times 1012 \text { par }
$$

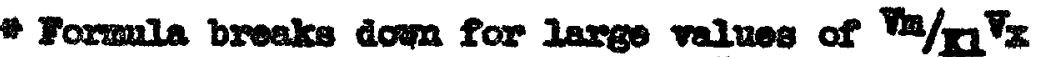

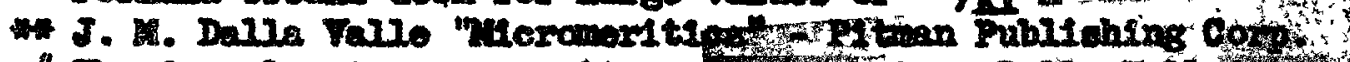

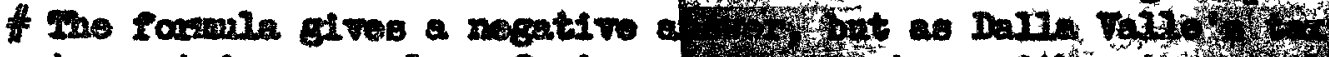

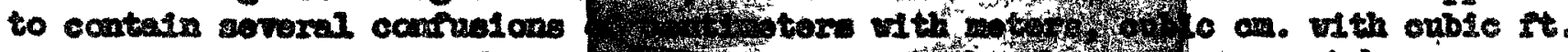
and the 11ke, wo lenore thes a 
The pick up enpports $2 \times 209$ p. per o. ft. at brsathing hoight.

If thore was arfirally radioactive contanination of 1 par, the canoentration In aix is now erfectively $2 \times 109$

$$
5.8 \times 2012
$$

- $3.5 \times 10^{-4}$ active particles per c. It.

350 e. ft. are broathod in a voridalay.

$\begin{aligned} \text { Therefore Inhalation rate } & =0.1 \text { active particles per day } \\ & =1 \text { por two vork reole }\end{aligned}$

This migt bo roprecentats Such atorme support particlos of average diamoter approcinatoly $2 \boldsymbol{p}$.

STppowe, naively, that the the cround is covered vith particles of diveter $2 \mathrm{p}$ in a nufform close-packed array. There vill bo $2 \times 1010$ partieles per seq ft on the surface layer, and 30 layers will be pickod up per hour. In a more moderate storm, postulate that just the surface lajor if picked up in one day. Fhis vould eive a coneentration at breathing lowi of $7 \times 10^{6}$ perticles per c. ft., barely rpcosmizable as a duct cloud. The active concontretion would be $3.5 \times 10^{-4}$ particles por $c$. Pt., and the inholation

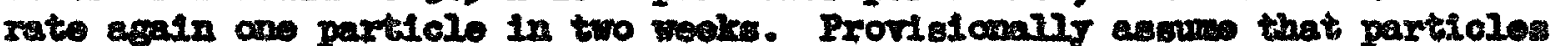
of alse $2 \mu$ hore activits not in excess of 2 mpe. Then 1 par on the ground appears to be afe provided that a perton stays out of readily visiblo clonds of dust. Simalar arguments must apply to particles piciced up by thersal currents. For eafoty, wo shall take 0.1 par (veak partialea culy) as a

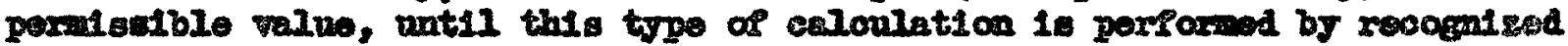
exports.

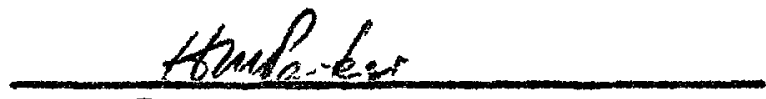

I. M. Parker

Iese/ hes

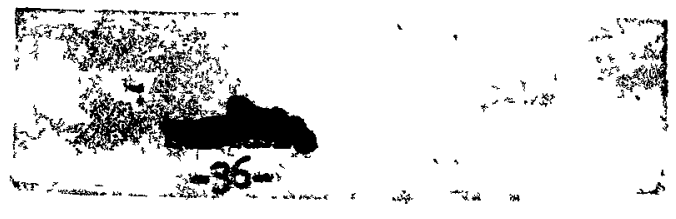




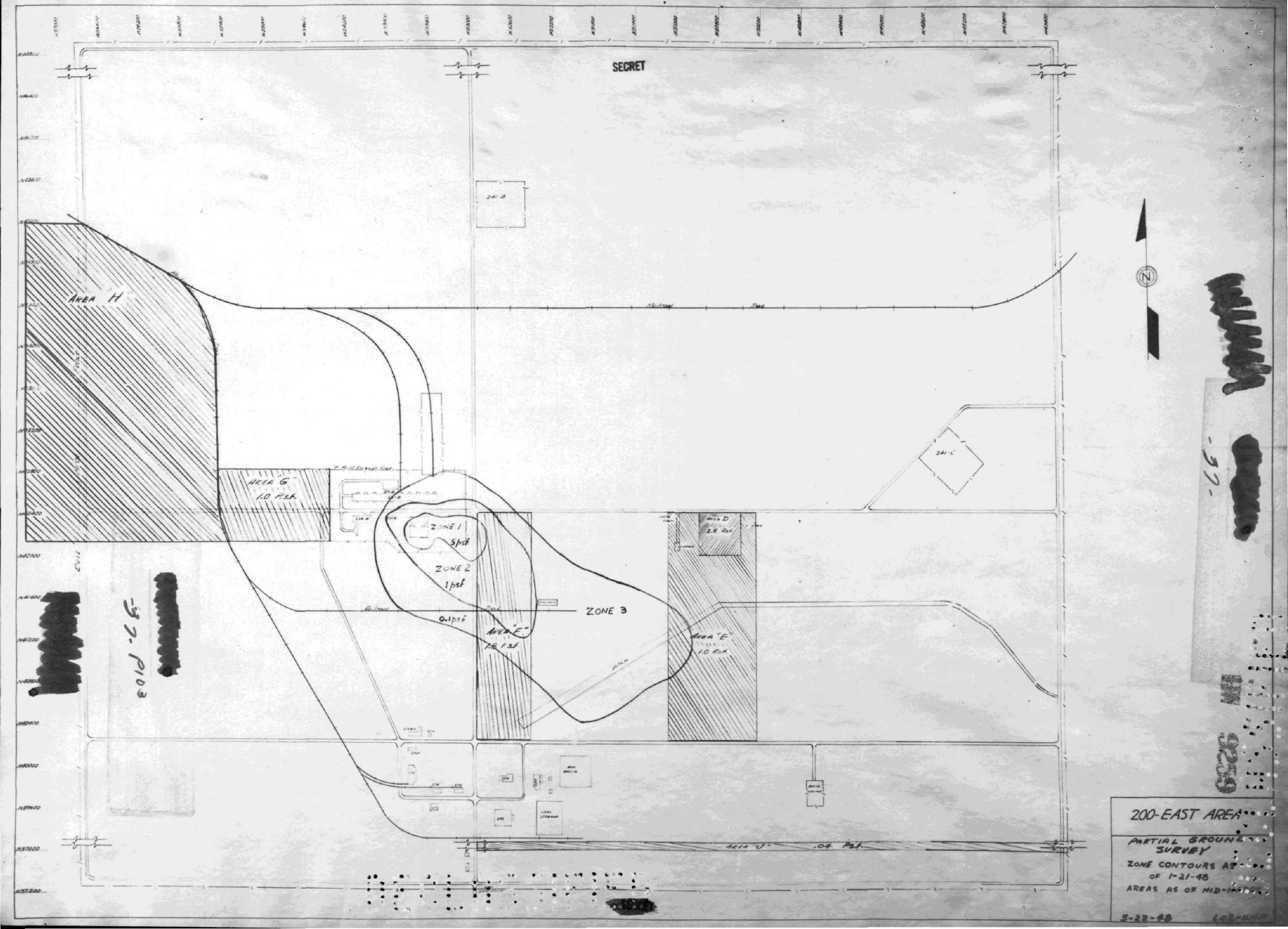




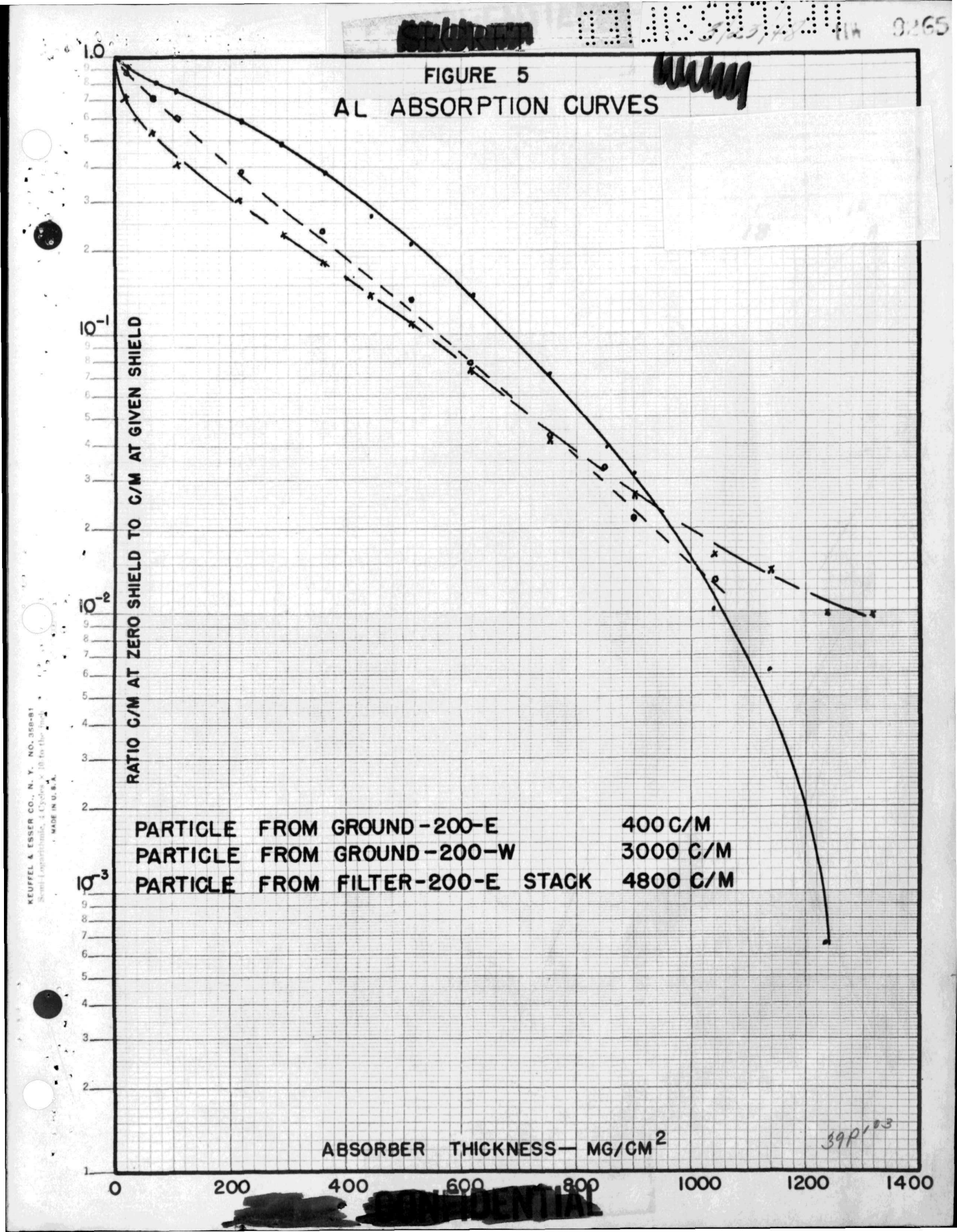




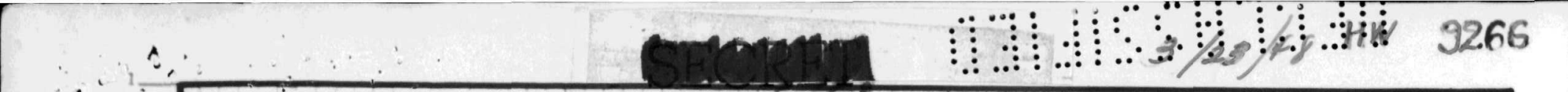

\section{FIGURE 9}

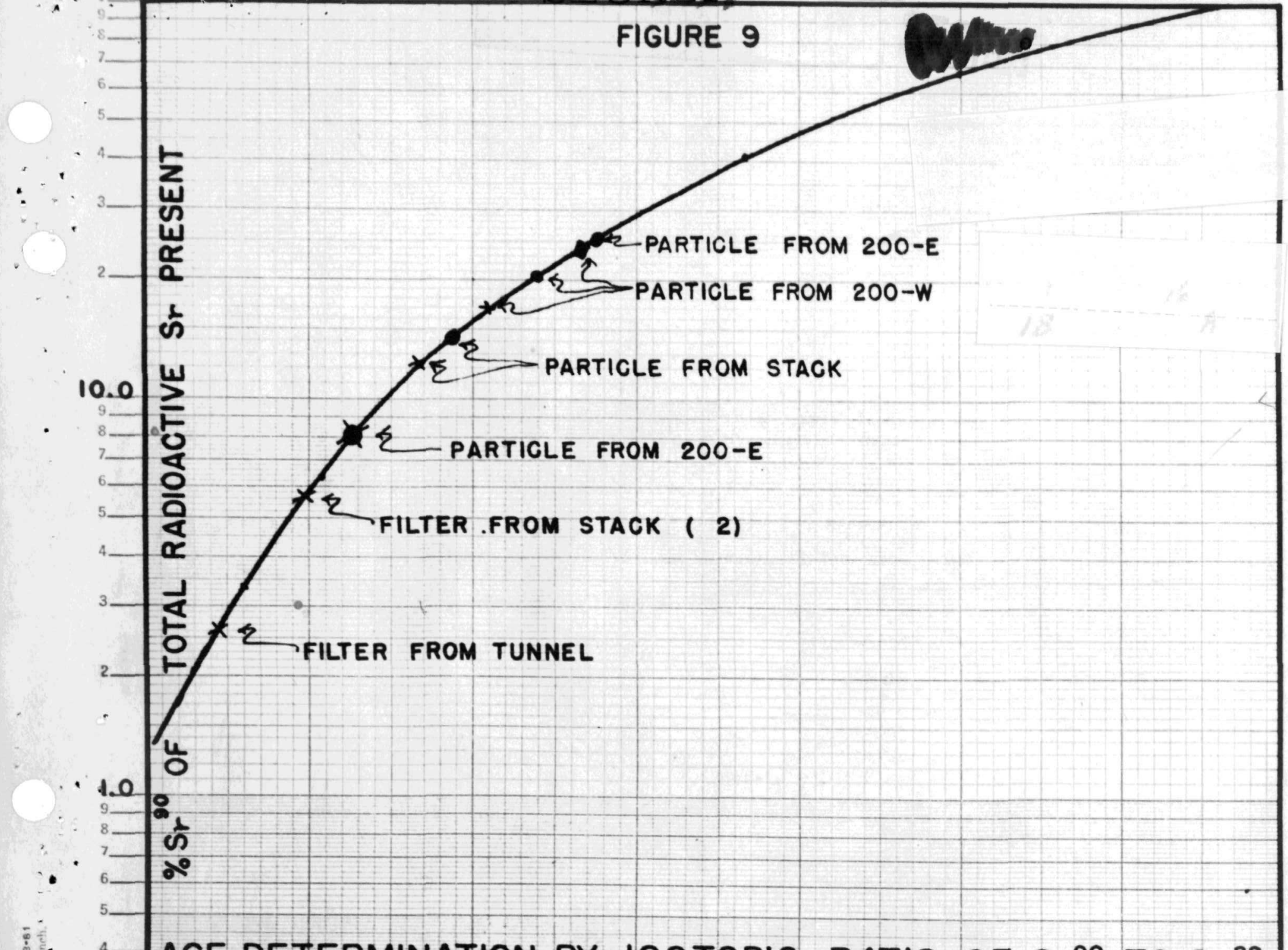

AGE DETERMINATION BY ISOTOPIC RATIO OF $\mathrm{Sr}^{90}$ TO $\mathrm{Sr}^{89}$

- COMPUTED POINTS

X FRACTION OBSERVED BY Y ANALYSIS OF DECAYED SY FRACTIONS

- Fraction observed by buildoup

- pOINTS OBSERVED bY decaY

DAYS 


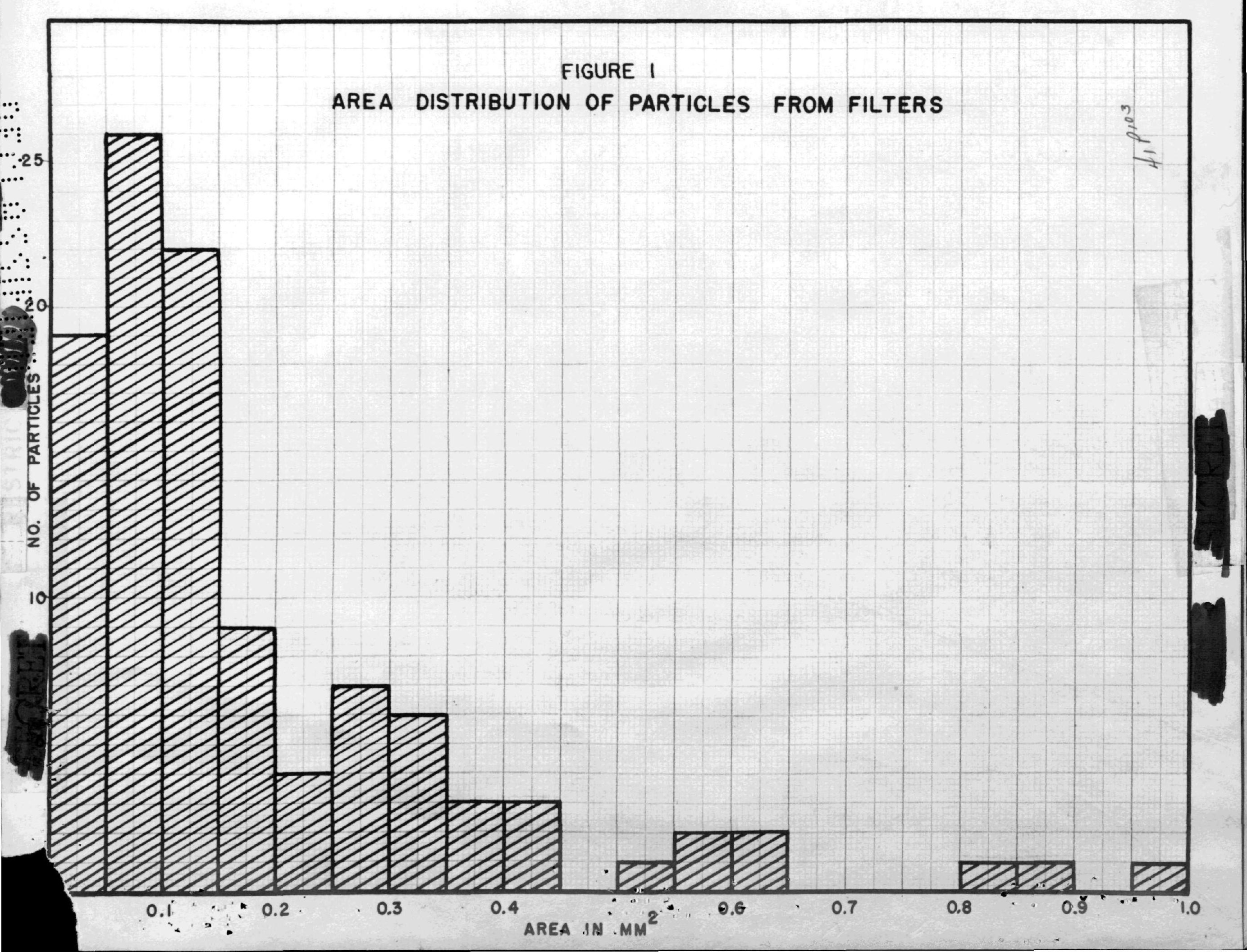


FIGURE 2

AREA DISTRIBUTION OF PARTICLES LESS THAN $0.05 \mathrm{MM}^{2}$

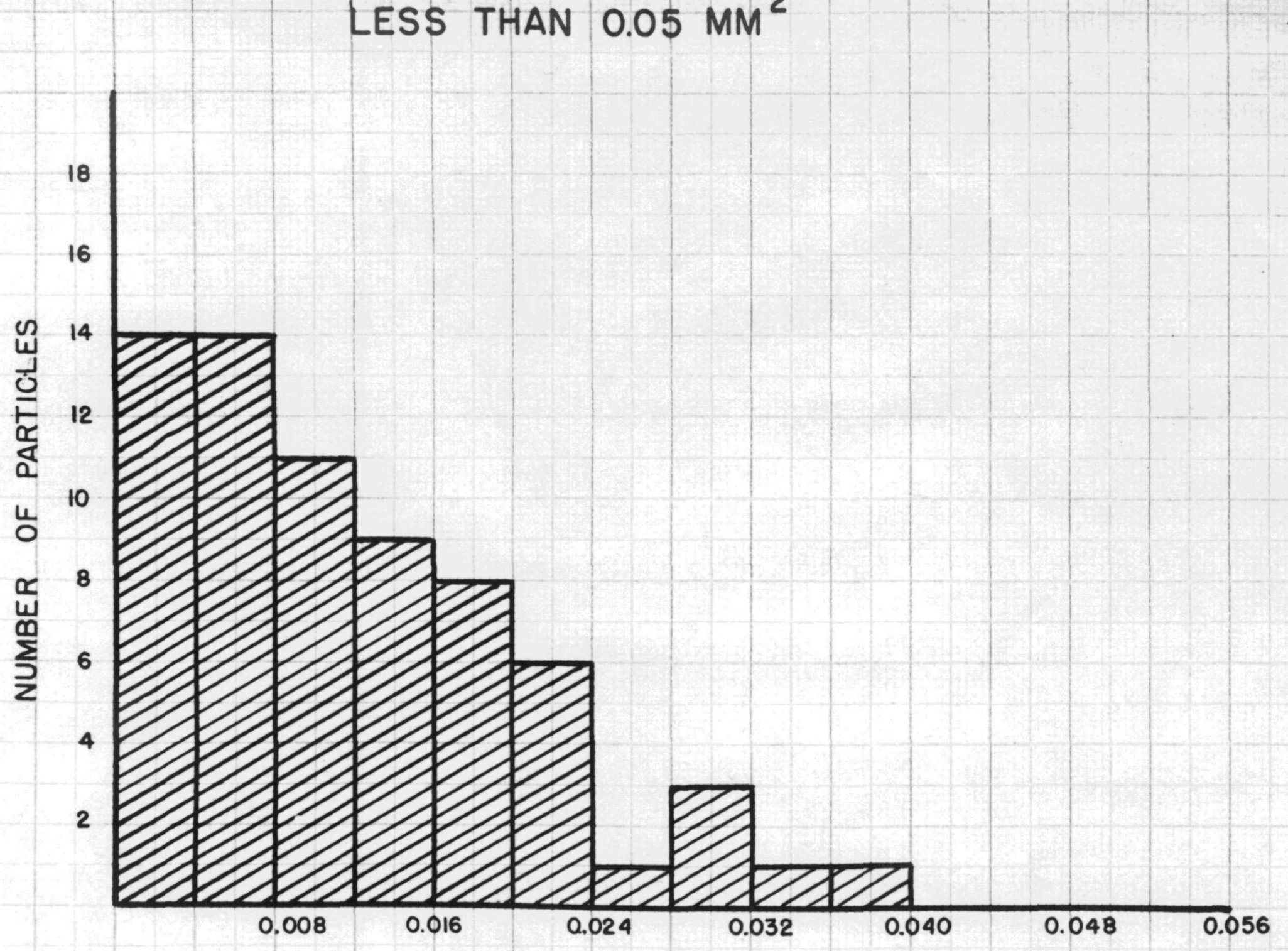

AREA IN $\mathrm{MM}^{2}$ 